Bond University

Research Repository

\title{
Empirical analysis supports the Hayne long run reform thesis
}

\author{
Millhouse, David
}

Published in:

Law and Financial Markets Review

DOI:

10.1080/17521440.2019.1602923

Licence:

Other

Link to output in Bond University research repository.

Recommended citation(APA):

Millhouse, D. (2019). Empirical analysis supports the Hayne long run reform thesis. Law and Financial Markets Review, 13(2-3), 162-187. https://doi.org/10.1080/17521440.2019.1602923

\footnotetext{
General rights

Copyright and moral rights for the publications made accessible in the public portal are retained by the authors and/or other copyright owners and it is a condition of accessing publications that users recognise and abide by the legal requirements associated with these rights.
}

For more information, or if you believe that this document breaches copyright, please contact the Bond University research repository coordinator. 


\section{Empirical Analysis Supports the Hayne Long Run Reform Thesis}

\section{Dr David G Millhouse}

Faculty of Law, Bond University, Australia

Correspondence: dmillhouse@millhouse.co

Dr David Millhouse is an Honorary Adjunct Senior Research Fellow, Faculty of Law, Bond University. This research paper contains material written for Dr Millhouse's $\mathrm{PhD}$ thesis entitled 'Systemic and cyclical failure in Australian financial services and financial products sectors: have weaknesses in law contributed to these failures?' That research was supported by an Australian Government Research Training Program Scholarship. This paper represents the views of the author only and does not purport to represent Bond University or its Faculty of Law. 


\title{
Empirical Analysis Supports the Hayne Long Run Reform Thesis
}

\begin{abstract}
Australia has arguably benefited from its market based regulatory system and progressed toward its first objective of an entrepreneurial wealth creating society competing with its global peers; the second objective, being investment stability and risk mitigation, has for many people been an abject disaster. ${ }^{1}$ Proposed reforms to balance entrepreneurial market conduct with investor and beneficiary risk mitigation rely on themes established by Cooper $^{2}$ (personal liability of superannuation trustee directors), $\mathrm{Heydon}^{3}$ (elimination of unhealthy culture), Hayne $^{4}$ (confluence of law and morality) and the Productivity Commission ${ }^{5}$ (trust). The Australian government must act. It must do so strategically. It must establish the nexus between the intent of the law and its practical implementation for those it purports to serve. Parliament has yet to debate these underlying causes. If it does, then it must confront the distinction between fiduciary and non-fiduciary duties and recognise the power of fiduciary law. Confused parliamentary leadership has facilitated corruption of the regulatory system. These are philosophical as well as legal questions. Hayne points to the need for a framework for the re-integration of the intent and spirit of the law with its statutory manifestations. This paper is that framework.
\end{abstract}

${ }^{1}$ David G Millhouse, 'Systemic and Cyclical Failure in Australian Financial Services and Financial Products Sectors: Have weaknesses in law contributed to these failures?' (PhD Thesis, Bond University, 2019) ch $1 \mathrm{~s} 6$.

${ }^{2}$ Jeremy Cooper, Review of the Governance, Efficiency, Structure, and operation of Australia's Superannuation System (Commonwealth of Australia, 30 June 2010).

${ }^{3}$ Commonwealth, Royal Commission into Trade Union Governance and Corruption (Interim Report, December 2014) 904 (Commissioner Heydon); Commonwealth, Royal Commission into Trade Union Governance and Corruption (Final Report, December 2015) ch 4, 10 (Commissioner Heydon).

${ }^{4}$ Commonwealth, Royal Commission into Misconduct in the Banking, Superannuation and Financial Services Industry (2018) (Commissioner Hayne).

${ }^{5}$ Australian Government Productivity Commission, Competition in the Australian Financial System (Draft Report, January 2018); Australian Government Productivity Commission, Superannuation: Assessing Efficiency and Competitiveness (Report No 91, 2018). 


\section{Introduction}

\subsection{Four Strategic Themes}

The primary findings of empirical research give rise to four reform objectives - re-establishment of trust in the investment chain based on fiduciary obligation; reform of related party transactions, value shifting through tunnelling and conflicts of interest; financial system architecture for implementation at the financial consumer level — financial planning and wealth management as a profession; and market conduct regulation for the $21^{\text {st }}$ century (including ASIC reform). Within each reform theme tactical statutory support to remedy failures in disclosure, develop Australia as a world financial centre, and NBFE governance are essential for successful implementation. These themes provide the framework on which to implement Hayne's longer term objectives. ${ }^{6}$

\subsection{The Four Ages}

The evolution of financial services and products regulation from 1981 to 2018 falls into four distinct periods, or Ages. These are: Deregulation and Entrepreneurship (1981-2001); Disquiet — Failures in Implementation (2002-2009); Reaction (2010-2013); and Statutes (2014 et seq). Each of these Ages are distinctive and trace the tension between encouragement of entrepreneurship and protection of investors and beneficiaries. These tensions are evident in the development of the law and in the profusion of statutes, inquiries, commissions, and research reports published in each of these Ages. Judicial interpretation of consequential accretive statutory interventions, particularly the Corporations Act, is not always kind to the parliamentary draftsmen.

A first theme from 1981-2018 has seen an increase in the number and size of statutes, often provoking judicial frustration and negative comment. ${ }^{7}$ Empirical analysis demonstrates that

\footnotetext{
${ }^{6}$ Hayne (n 4) vol 1 494-496.

${ }^{7}$ Millhouse (n 1) see, eg, ch 1 n 38.
} 
legislation (the 'Age of Statutes') ${ }^{8}$ has not prevented manifestation of systemic problems or reduced their cyclical recurrence. Instead, it has created a large compliance industry with attendant direct and indirect costs. These costs are ultimately borne by beneficiaries and investors. They also manifest in market consolidation in attempts to capture economies of scale in an attempt to reduce unit costs to those investors and beneficiaries. Regulatory intervention into the superannuation sector requiring consolidation is an example. Statutory evolution has been and remains politically contested reducing its effectiveness as lobby groups masquerading as industry and professional associations pursue their particular interests.

A second theme is the role of fiduciary duties. As Donald accurately points out, misuse of the adjective fiduciary by politicians and lobby groups has resulted in a mismatch of community expectations and the reality of fiduciary law in the Australian financial sector. ${ }^{9}$ Principles based general law has often provided the basis for the resolution of many specific cases in the empirical analysis. 'Each of statute and equity influences the other [although] there is no judicial power to sunset some statutes as there is in the common law. ${ }^{10}$ In the meantime,

It is ironic, then that those same political processes that are privileging these nobler qualities [of fiduciaries] are in fact de-coupling the regulatory regimes from the general law antecedents in which those qualities were initially expressed. Political processes are ensuring that what the law expects of Mason J's quintessential fiduciaries, or at least those whose activities encroach on areas of public policy, are regulated by multi-layered, highly specific, bespoke regulatory regimes that largely eclipse the proscriptions and prescriptions of the general law. ${ }^{11}$

\footnotetext{
${ }^{8}$ Mark Leeming, 'Equity: Ageless in the "Age of Statutes"' (2015) 9(2) Journal of Equity 108.

${ }^{9}$ M Scott Donald, 'Regulating for fiduciary qualities of conduct' (2013) 7(2) Journal of Equity 142 [1].

${ }^{10}$ Leeming (n 8).

${ }^{11}$ Donald (n 9) 142 [2].
} 
Accretive legislative change is not enough. Whilst 'we now live in an age of statutes and not of the common law, ${ }^{12}$ statutes have not eliminated systemic failures and their cyclical manifestations. '[C]omplying merely with the regulatory requirements may well leave the investment bank in breach of the fiduciary obligation'. ${ }^{13}$ In other words, compliance with the statute may expose a director to breaches of the general or case law on fiduciary obligations. ${ }^{14}$ Corruption rooted in cultural mores ${ }^{15}$ requires a rethink of assumptions of robustness in statutory construction', ${ }^{16}$ and the adoption of 'principles drawn from the law of trusts and from fiduciary law... ${ }^{17}$ The statutes seek to manage whereas the solution is excision. Tuch concludes: 'These problems are at the core of the structure of the financial markets'. ${ }^{18}$ Trustee standards are based on prohibition, not prioritisation, as is presently the case under the Corporations Act. This is one reason why the supremacy of fiduciary duties and trustee standards across the NBFE sector becomes manifestly important.

\subsection{Community Expectation - The Search for Blame}

The Australian NBFE sector has been plagued with abhorrent and egregious conduct associated with related party transactions (RPTs) and consequential conflicts of economic interest. The

${ }^{12}$ Paul Finn, 'Public Trusts, Public Fiduciaries' (2010) 38 FLR 350.

${ }^{13}$ Andrew Tuch, 'Investment Banks as Fiduciaries: Implications for Conflicts of Interest' (2005) 29 Melbourne University Law Review 478, 515.

${ }^{14}$ In financial advice, see, eg, Simone Degeling and Jessica Hudson, 'Fiduciary Obligations, financial advisers and FOFA' (2014) 32 Companies and Securities Law Journal 527; Simone Degeling and Jessica Hudson 'Equitable money remedies against financial advisers who give "advice about advice" (2015) 33 Companies and Securities Law Journal 166.

${ }^{15}$ Commonwealth, Royal Commission into Trade Union Governance and Corruption (Final Report, December 2015) (Commissioner Heydon).

${ }^{16}$ Finn, 'Public Trusts, Public Fiduciaries' (n 12) 336.

${ }^{17}$ Ibid 335 .

${ }^{18}$ Tuch (n 13) 516. 
conduct may not strictly amount to legal malfeasance. Statutes and contracts are focussed on legal rights and interests rather than investor value outcomes. Correlation analysis of 199 senior court judgments demonstrates Australian propensity for related party transactions and their consequences. ${ }^{19}$ Notably, other professions are limited in respect of related party conduct. It is one of the factors preventing Australia from having a properly professional financial services sector.

The scope and scale of financial damage, direct and indirect, led directly to community anger, political pressure, and to the search for remedies and scapegoats. Community expectations were different from market realities across much of the NBFE sector. Resulting economic hardships inevitably lead to emphasis on past losses. There is no broad public understanding of regulators' mandates nor of the legal constraints under which they operate, particularly of the Australian Securities and Investments Commission (ASIC). There is unmet public expectation of a zero failure system.

\subsection{Australian Propensity for Misfeasance, Malfeasance and Non-Feasance}

'The financial services industry is particularly vulnerable to the risk of international fraud'. ${ }^{20}$ The Australian Crime Commission noted that 'Serious and Organised Investment Fraud is not an opportunistic crime, but a calculated, sophisticated, organised criminal event that can [attack]

${ }^{19}$ Millhouse (n 1) ch 3 tab 3.25. Where related parties were involved, $93.42 \%$ of those same cases involved deceptive, misleading or unconscionable conduct; $95.31 \%$ involved dishonesty, and $100 \%$ involved breaches of directors' duty. See also Australian Government Productivity Commission, Competition in the Australian Financial System (Draft Report, January 2018) ch 7 'Dominance through integration', fig 7.1; ch 11 'General insurance providers', fig 11.3. See also Kevin Yi Liu, Australian Superannuation: Operational Structure, Investment Performance and Trustee Governance (PhD Thesis, The University of Sydney, 2013) 166-176.

${ }^{20}$ Submission to Senate, PJC, Parliament of Australia, Inquiry into the collapse of Trio Capital (2012), Australian Custodian Services Association 433. 
experienced investors... ${ }^{21}$ Task Force Galilee was established in 2011 as a multi-agency response to these crime threats. Whilst serious, international frauds have been comparatively small and rare by comparison with investor losses arising from internal systemic failures quantified in the empirical analysis.

Closer to home, there are many thousands of cases of egregious behaviour. ${ }^{22}$ These cases arose from financial products investment through the Wallis inspired processes of disclosure, financial advice, and assumptions of a financially literate clientele. Public pressure and judicial proceedings led inter alia to reviews of ASIC's performance in 2014 and $2015,{ }^{23}$ a further Parliamentary Inquiry into agribusiness MIS (Bitter Harvest), ${ }^{24}$ and the Financial System Inquiry ${ }^{25}$ in 2014. For superannuation entities, a continuation of the Stronger Super ${ }^{26}$ agenda. The Heydon Royal Commission ${ }^{27}$ into registered organisations corruption paved the way for legislative reform of these systemically important entities, followed by Hayne in 2018. These cases demonstrate, with

${ }^{21}$ Australian Crime Commission, Serious and Organised Investment Fraud in Australia (2012) 1.

${ }^{22}$ See, eg, Australian Government, The Senate Economics Reference Committee, Performance of the Australian Securities and Investments Commission (June 2014); The Senate Economics Reference Committee, Parliament of Australia, Agribusiness managed investment schemes - Bitter Harvest (2016) chs 3, 31; 4, 37; 6, 75; 11 ('Bitter Harvest').

${ }^{23}$ Australian Government, The Senate Economics Reference Committee, Performance of the Australian Securities and Investments Commission (June 2014); Karen Chester, Mark Gray, and David Galbally, 'Fit for the future: A capability review of the Australian Securities and Investments Commission' (Australian Government Treasury Report, December 2015).

${ }^{24}$ Senate Economics Reference Committee, Parliament of Australia, Agribusiness managed investment schemes - Bitter Harvest (2016) chs 3, 31; 4, 37; 6, 75; 11 ('Bitter Harvest').

${ }^{25}$ David Murray, Financial System Final Report (Australia Treasury, 2014).

${ }^{26}$ Cooper (n 2).

${ }^{27}$ Heydon (n 3). 
the exception of consumer credit and superannuation default funds, that investors are often treated as capital providers rather than consumers. ${ }^{28}$

Community expectation that ASIC can police every commercial transaction is unaffordable, undesirable and unachievable. Empirical analysis indicates ASIC to have been the plaintiff in approximately $64.32 \%$ of the cases in that analysis. ASIC's responsibilities include inter alia more than 2.1 million companies, 490 Responsible Entities (RE's), 861 custodians, more than 2,000 trustee entities, more than 5,000 financial advice entities with 24,323 advisers. ${ }^{29}$ This mandate is proposed to be extended. ${ }^{30}$ However, it is 'not feasible to contract [ex ante] for every contingency'. ${ }^{31}$ There is evidence that government lacks insight into ASIC's need for governance and culture reform. ${ }^{32}$ It is not clear that 'underfunding' has been a problem, ${ }^{33}$ but there are dissenting views. ${ }^{34}$ Revenue has been reformed, but governance, financial allocations and human resources must follow function. Behavioural economics research casts substantial doubt on reformed ASIC funding systems. These are likely to prove costly to its clients and not address the

${ }^{28}$ See, eg, Dimity Kingsford Smith, 'ASIC Regulation for the investor as consumer' (2011) 29 Companies and Securities Law Journal 327.

${ }^{29}$ Australian Government, Proposed Industry Funding Model for the Australian Securities and Investments Commission (Proposals Paper, November 2016).

${ }^{30}$ Australian Government Productivity Commission, Competition in the Australian Financial System (Draft Report, January 2018) ch 8 pt 17.

${ }^{31}$ Sven Hoeppner and Christian Kirchner, 'Ex Ante versus Ex post Governance: A behavioural perspective' (2016) 12(2) Review of Law and Economics 485, 232.

${ }^{32}$ Australian Government, Proposed Industry Funding Model for the Australian Securities and Investments Commission (Proposals Paper, November 2016) 4.

${ }^{33}$ Chester, Gray and Galbally (n 23) 13.

${ }^{34}$ See especially Pamela Hanrahan, ‘ASIC and managed investments' (2011) 29 Companies and Securities Law Journal 297 and Dimity Kingsford Smith, 'A harder nut to crack? Responsive Regulation in the financial services sector' (2011) 44 (3) University of British Columbia Law Review 702. 
underlying systemic problem. '[S]uch regimes increase governance costs without reducing the residual governance problems., ${ }^{35}$

\subsection{Statutory Reform through the Ages}

Statutory reform has materially evolved the nature of regulation of financial products and financial services that largely subsume general law principles even as they employ similar language. 'We live in the 'Age of Statutes'. ${ }^{36}$ Insightfully, the intrusion of statute 'is all too evident in both the FoFA and Stronger Super reforms. It is manifest in the sheer number of provisions that have been required to achieve a small number of easily articulated objectives'. 37 'The provisions relating to the prohibition of certain types of "conflicted remuneration" are particularly Byzantine'. ${ }^{38}$

Future of Financial Advice (FoFA) is 'a tragedy', a 'means of [financial] product distribution'. ASIC 'needs a big shake-up with high calibre people', is subject to 'cronyism' with 'ideology over-riding facts', 'just doesn't get it', and 'powerless to act against known malfeasors'. These are personal views of interviewees who participated in the qualitative research. Top decile and quartile empirical analysis quantifying investor losses and their causes provides holistic support for such excoriating criticism. Such criticisms should not be restricted to ASIC. It is restricted by its mandate and by parliamentary drafting of relevant statutes. The Australian Prudential Regulation Authority (APRA) and the Fair Work Commission (FWC), perhaps because of their much smaller stakeholder groups, were not subjected to such invective despite stated concerns of political influence and accountability.

\footnotetext{
${ }^{35}$ Hoeppner and Kirchner (n 31) 249.

${ }^{36}$ Dimity Kingsford Smith, 'Is "due diligence" dead? Financial Services and products disclosure under the Corporations Act' (2004) 22 Company and Securities Law Journal 130.

${ }^{37}$ Donald (n 9) 142 [3].

${ }^{38}$ Ibid [1].
} 
Suggested solutions ${ }^{39}$ include overwhelming support for a better culture, extension of fiduciary obligation to all parts of the investment chain, financial planners as educators, university standard training for directors and trustees, reform of ASIC's operations, Canadian style SelfRegulatory Organisation (SRO) architecture, and an independent arbiter to reduce reliance on the courts. $^{40}$

Resolution also includes emulation of models and standards from other jurisdictions which themselves have dealt with similar systemic failures. There are examples where professional and industry associations are quasi-regulators working from the bottom up, educative and consultative, thereby reducing inexhaustible demands for market conduct services from the central regulator, making for more effective 'Responsive Regulation'. ${ }^{41}$ Scholarly research has demonstrated the difference between compliance based cultures and values based cultures and how 'assumptions of rationality in economic theory are contradicted by experimental evidence'. ${ }^{42}$ This is important behavioural economics research with global multi-jurisdictional implications ${ }^{43}$ but receiving only limited scholarly attention in Australia.

The basis of necessary infrastructure exists in Australia today. Ipso facto, ASIC can become ex ante and supervisory rather than ex post and reactive, its present posture impractical even with huge additional resources. It can evolve to apply the lessons of Cooper, Heydon, Hayne and the Productivity Commission. Behavioural economics scholarly research supports this change in

\footnotetext{
${ }^{39}$ From greater than $50 \%$ of respondents in each city.

${ }^{40}$ Administrative Appeals Tribunal and Takeovers Panel were cited as examples.

${ }^{41}$ Dimity Kingsford Smith, 'A harder nut to crack? Responsive Regulation in the financial services sector'
} (2011) 44(3) University of British Columbia Law Review 695, 702.

${ }^{42}$ Don Mayer, Anita Cava and Catharyn Baird, 'Crime and Punishment (or the Lack Thereof) for Financial Fraud in the Subprime Mortgage Meltdown: Reasons and Remedies for Legal and Ethical Lapses' (2014) 51(3) American Business Law Journal 515, 534 citing Dan Ariely, Predictably Irrational: The Hidden Forces That Shape Our Decisions (Harper Perennial, 2010).

${ }^{43}$ Mayer, Cava and Baird (n 42) 541. 
posture, regarding ex post strategies as 'behaviourally dysfunctional' requiring a 'counterintuitive shift of rule-making competencies: from public to private ordering. ${ }^{, 44}$ In effect, Responsive Regulation, presently given lip-service rather than practical implementation. ' $[\mathrm{I}] \mathrm{t}$ is doubtful whether [ex post] monitoring can be done cost effectively'. ${ }^{45}$ Evolution to an ex ante Responsive Regulation model requires discipline in those that implement it. The Damoclean Sword over improper conduct is to be provided by fiduciary obligation in the investment chain enforced by effective regulators and much greater levels of financial literacy.

\subsection{A Systemic Problem}

'[R]elated party transactions are inherently problematic under any circumstances ${ }^{\text {' }}{ }^{4}$. They 'undermin[e] ... fiduciary responsibility... ${ }^{47}$ RPTs 'divert value from a corporation' ${ }^{48}$ Their cousin, tunnelling, is the "transfer of resources out of a company [or other entity] to its controlling shareholder ... [by] dominant shareholders and managers'. ${ }^{49}$ Prime Trust ${ }^{50}$ illustrates how value shifting by related parties can occur in Australia, its lawfulness contested in senior courts. Such deficiencies in the law strike directly at the veracity of Australia's investment landscape.

\footnotetext{
${ }^{44}$ Hoeppner and Kirchner (n 31) 227.

${ }^{45}$ Ibid 231.

${ }^{46}$ Duncan C Jessup, John H Farrar and Susan Watson, 'Related Party Transactions in New Zealand: An Empirical Study of a Flawed System' (2012) 30(2) Companies \& Securities Law Journal 110, 113. ${ }^{47}$ Ibid.

${ }^{48}$ Luca Enriques, 'Related Party Transactions: Policy Options and Real-World Challenges (with a Critique of the European Commission Proposal)' (2015) 16 European Business Organization Law Review 1-2. ${ }^{49}$ Ibid 3.

${ }^{50}$ Lewski v ASIC (No 2) [2017] FCAFC 171 [190] (Greenwood, Middleton, and Foster JJ).
} 
Some argue that RPTs are in the best interest of the company but this laxity in regulation is a systemic failure leading directly to creeping corruption. ${ }^{51}$ Shareholder approval for a specific transaction easily leads to transfer of value and loss of control since only specific transactional approval is required, not approval of its long term value impact. RPTs are regulated using a number of legal tools, of varying efficacy and depend on the efficiency of enforcement. Prohibition of some transactions, including related party loans and loan guarantees used to gain control would be effective in some Australian creeping corruption cases, but may not be in the best interest of the company when the related party is the only willing participant. Selective prohibitions may be more pragmatic than a total prohibition.

\subsection{Comparative Insights}

The Untreue ${ }^{52}$ principle governs intent, now codified in EU law and supported by the German Corporate Governance Code as general law. German directors are required to observe the spirit and intent of the law, not only its statutory manifestations. EU regulation of related party transactions recognises they may have potential value, has not pursued the prohibition philosophy, provides for business judgment but balanced by codified civil law counterweights. This architecture reflects fiduciary stewardship concepts. This is not so in Australia unless there is a broadened fiduciary relationship where, as in the UK, '[i]t [creative compliance] is essentially the practice of using the letter of the law to defeat its spirit, and to do so with impunity'. ${ }^{53}$

\footnotetext{
${ }^{51}$ In New Zealand it led to the complete collapse of its finance company sector: 'almost $40 \%$ of all RPT's are with executives...' 'The result is that New Zealand has been a relatively safe haven for Australian fraudsters' quoted in Jessup, Farrar and Watson (n 46) 136-38.

${ }^{52}$ Luca Enriques, 'Related Party Transactions: Policy Options and Real-World Challenges (with a Critique of the European Commission Proposal)' (2015) 16 European Business Organization Law Review 1, 24.

${ }^{53}$ Simon Ashby, 'The Turner Review on the Global Banking Crisis: A Response from the Financial Services Forum' (Nottingham University, 2009) 17.
} 
The UK has, by widening director statutory responsibility to company long term success, introduced subjectivity. Disclosure, including the nature of the related party interest not just its existence, and prior fully informed consent of the disinterested members of the company form the basis of modern UK related party transaction governance. ${ }^{54}$

Canadian regulation of financial advice requires consideration of whether a conflict may be 'expect[ed] to arise between the firm including each individual acting on behalf of the firm and its client'. ${ }^{55}$ Disclosure of itself is not sufficient. There must be a proactive business system of identifying conflicts of interest with prospective clients by the firm and participants in it, 'consistent with the best interests of the client', ${ }^{56}$

\subsection{Excision: Prohibition Not Prioritisation}

RPTs and tunnelling are so deep seated and problematic in Australian NBFEs that cultural change requires at least selective prohibition, not prioritisation. This excision should continue until governance practices demonstrably meet community expectations of trust and loyalty. ASIC needs RPT ex ante review and prevention powers, directly addressing the causes of systemic failure identified in the correlation analysis. The evolution of Australian superannuation law provides guidance although it still allows prioritisation. In the superannuation sector, ' $71 \%$ of retail funds ... employ related-party service providers, compared with $52 \%$ of not-for-profit funds', with differing patterns of ownership and control. ${ }^{57}$ 'Extremely high levels of concentration are ... exhibited in a number of outsourcing markets', ${ }^{58}$ most particularly asset allocation consulting, audit, actuarial and

\footnotetext{
${ }^{54}$ Companies Act 2006 (United Kingdom) s 200.

${ }^{55}$ National Instrument 31-103CP (Canada) pt 13.4.

${ }^{56}$ Approved Person responsibility to address conflicts of interest (Investment Industry Regulatory

Organization of Canada) Rule 42.2.

${ }^{57}$ Kevin Yi Liu, 'Australian Superannuation: Operational Structure, Investment Performance and Trustee

Governance' (PhD Thesis, The University of Sydney, 2013) 147.

${ }^{58}$ Ibid $167-8$.
} 
custody. APRA's ex ante supervisory posture and small number of supervised entities is a different proposition to the difficulties presently facing ASIC. ASIC will need data. This will be provided by each NBFE proactively developing their conflicts of interest register as part of lodgement of relevant offer documents and supporting related party contracts. Whilst not the same as notarisation and commercial court lodgement powers in German law, it would emulate that process extending contractual veracity to external independent review.

Failure to disclose will result in loss of BJR protection under Corporations Act s 180(2)(b). It is a more stringent test than the present conflicts register which only requires disclosure of actual conflicts of interest. If these are reviewed at all, it is normally ex post. Different conflict of interest standards presently arise in NBFEs because of the fragmented statutory architecture: excision through prohibition will provide a period through which policy and statutory harmonisation can occur.

For some vertically integrated NBFEs, this policy will be problematic, requiring divestment of controlled entities but an opportunity for directors to focus on their core business. 


\section{Judicial Interpretations}

Legal analysis of cases which address the Wallis reform principles of financial advice and disclosure sustain these arguments. The cases refine the law applying to each of the Wallis principles. However, these cases, many of them useful, are piecemeal, primarily tactical and always after the fact (ex post). Rarely do they strike at the heart of the fundamental reason for systemic failure, namely statutory subsuming and deficient enforcement of fiduciary principles of loyalty in the investment chain.

They do strike directly at a major reason for systemic failure, namely statutory complexity and uncertainty. Complexity and sheer volume of detail provide cover for creeping corruption (in UK terminology, creative compliance). Legal analyses of similar issues in like jurisdictions together with revelations from Australian case law provides a sound rationale for more stringency in policy sufficient to deter director and trustee malfeasance.

\subsection{Fiduciary Duty}

Fiduciaries concurrently exercise fiduciary and non-fiduciary duties. Contractual and other nonfiduciary duties may co-exist with fiduciary duties. They should always be exercised to the benefit of the beneficiary. ${ }^{59}$ So, the sum of the duties exercised by a fiduciary are not the same as fiduciary duties. Whilst financial advisers have general law fiduciary duty to act in their clients' interest, this is not the same as their best interest. ${ }^{60}$ Nor is it the same as the statutory overriding formulation relying on process rather than outcome. ${ }^{61}$

\footnotetext{
${ }^{59}$ M Scott Donald, “'Best” interests?' (2008) 2 Journal of Equity 253.

${ }^{60}$ Stephen Corones and Thomas Galloway, 'The effectiveness of the best interests duty — enhancing consumer protection?' (2013) 41 Australian Business Law Review 5, 16.

${ }^{61}$ See Millhouse (n 1) ch 4 s 3.4.
} 
Acting in a positive way in satisfaction of the best interests duty is contested as nonfiduciary in character (unlike the US and Canada), ${ }^{62}$ despite the obligation of fiduciary loyalty which 'underlies and unifies other fiduciary duties'. ${ }^{63}$ As Finn opines, '[t]he scope, even the independent existence of, this duty are matters of contest in private law ... [with] no uniformly agreed and accepted understanding of what the description 'fiduciary powers' signifies in private law'. ${ }^{64}$

Recent judicial opinion suggests otherwise: ${ }^{65}$

Positive, prescriptive duties may arise as a consequence of their being 'no decision of which I am aware binding on this court to hold that the fiduciary duties of directors to their companies are so limited ${ }^{66}$ [to proscriptive duties]. It is a matter of opinion as to what the law is. ${ }^{67}$

Confusion reigns in the articulation of these principles in the terminology used by the legislature and subsequently in the media where fiduciary duty and best interest duty continue to be used interchangeably without distinguishing between proscriptive and prescriptive duties. This arises from recent context specific judicial interventions which should have limited holistic application to fiduciary duty in other broader contexts. It results in Australia becoming a legal outlier in fiduciary

${ }^{62}$ Donald (n 59) 251; see also Corones and Galloway (n 60), 11.

${ }^{63}$ Rosemary Langford, 'The Bona Fide Fiduciary Loyalty of Australian Company Directors' (PhD Thesis, Monash University, 2013) 314 [1.1] citing Fitzsimmons $v$ The Queen (1997) 23 ACSR 355.

${ }^{64}$ Finn, 'Public Trusts, Public Fiduciaries' (n 12) 342-3 citing Geraint Thomas, 'The Duty of Trustees to Act in the "Best Interest" of their Beneficiaries' (2008) 2 Journal of Equity 177. See also John Lehane, 'Delegation of Trustees' Powers and Current Developments in Investment Funds Management' (1995) 7 Bond Law Review 36.

${ }^{65}$ Babcock \& Brown DIF 111 Global Co-Investment Fund, LP v Babcock \& Brown International Pty Limited (No 2) [2017] VSC 556 [40] (Hargrave J); Westpac Banking Corporation v The Bell Group Ltd (in liq) [No3] [2012] WASCA 157 [914], [1214] (Lee AJA, Drummond AJA, Carr AJA).

${ }^{66}$ Westpac Banking Corporation v The Bell Group Ltd (in liq)(No3) [2012] WASCA 157 [1961] (Drummond AJA).

${ }^{67}$ Ibid [1976]-[1978]. 
law setting its jurisprudence apart from most comparative jurisdictions by significantly narrowing the definition and operation of fiduciary duty, relying on statutes which, as empirical analysis demonstrates, have manifestly failed those that they purportedly serve.

Recent Australian jurisprudence restricted fiduciary duties to proscription. '[J]udicial thinking about the content of fiduciary duties has changed significantly over the last decade ... [being to] confine the fiduciary component of the overall relationship to a number of specific duties' ${ }^{68}$ Proscription requires restraint whereas prescription requires action (for obligatory duties) and positive actions for discretionary duties. ${ }^{69}$

But the proscriptive nature of general law fiduciary duty is not a unanimous view: ${ }^{70}[\mathrm{~T}]$ he law of this country does not otherwise impose positive legal duties on the fiduciary to act in the interests of the person to whom the duty is owed', ${ }^{71}$ with Kirby J dissenting.

A clear distinction between proscriptive and prescriptive duties may exist in some cases, but many situations could potentially be classified as involving duties of either kind ... most but not necessarily all, fiduciary duties are proscriptive. However, it is dangerous to treat it as a talisman: it does not identify the reason for the existence (and hence the nature) of fiduciary duties. $^{72}$

Funds management entities, including promoters, and their directors are fiduciaries, although some

${ }^{68}$ Aequitas $v$ AEFC [2001] NSWSC 14 [283] (Austin J).

${ }^{69}$ Langford, 'The duty of directors to act bona fide in the interests of the company' (n 63) 219.

${ }^{70}$ Pilmer v Duke Group Ltd (in liq) [2001] HCA 31 (Mc Hugh, Gummow, Hayne, Callinan, Kirby JJ).

${ }^{71}$ Breen $v$ Williams (1996) 186 CLR 71 cited in Langford 'The duty of directors to act bona fide in the interests of the company' (n 63) 228.

72 Westpac Banking Corporation v The Bell Group Ltd (in liq) (No3) [2012] WASCA 157 [1957] (Drummond AJA). See, eg, Matthew D J Conaglen, 'Fiduciary Liability and Contribution to Loss' (2001) 60 Cambridge Law Journal 482. See also Nicholas Saady, 'The Dangerous Dichotomy: Abandoning the 'Proscriptive' and 'Prescriptive' Classification of Fiduciary Duties and the 'Proscriptive Limitation' (2018) 30(2) Bond Law Review 275. 
'major investment banks have indicated publicly their belief that they operate unconstrained by fiduciary obligations'. ${ }^{73}$ Where Managed Investment Schemes (MIS) are contractual rather than express trusts, that does not exclude the application of fiduciary principles, and a court may treat the relationship 'as fiduciary under established principles of equity'. ${ }^{74}$ There is a tension between statutory prioritisation and fiduciary prohibitions, the result being whether an investment bank or funds manager 'is obliged by fiduciary principles to avoid positions of conflict..., ${ }^{75}$ or not. Fiduciary relationships can be created by reasonable expectation where the client relies on the advice proffered. ${ }^{76}$ Presently for wholesale investors in Australia, that relationship can be avoided by contract. ${ }^{77}$ For retail investors, it is subsumed by the Corporations Act. ${ }^{78}$

Fiduciary standards mitigate malfeasance by reducing the power imbalance resulting from asymmetries of knowledge and comprehension. They align interests. Fiduciary law is more than 'legal polyfilla' ${ }^{79}$ requiring legitimate and reasonable client expectations of best interest to have primacy over contract. So who is categorised as a fiduciary has considerable importance to the investing community. '[A]11 of these are bound to the investor-beneficiaries by a web of fiduciary relationships both orthodox as well as unusual'. ${ }^{80}$ In a consolidating Australian NBFE market, these multiplicity of responsibilities are likely to become more widespread.

\footnotetext{
${ }^{73}$ Tuch (n 13) 479.

${ }^{74}$ Pamela F Hanrahan, Funds Management in Australia: Officers Duties and Liabilities (LexisNexis Butterworths, 2007) 52.

75 Tuch (n 13) 488.

${ }^{76}$ Commonwealth Bank of Australia v Smith [1991] 42 FCR 390 (Davies, Sheppard, and Gummow JJ); Aequitas $v$ AEFC [2001] NSWSC 14 (Austin J).

${ }^{77}$ Tuch (n 13) 500-502.

${ }^{78}$ Corporations Act 2001 (Cth) ss 961 A, B.

${ }^{79}$ Fiduciary Duties of Investment Intermediaries (Law Commission UK, Paper No 350, 30 June 2014) [3.1].

${ }^{80}$ Australian Securities Commission v AS Nominees Limited, Ample Funds Limited, AS Securities Limited and Peter Grenfell Windsor [1995] FCA 1663 [58] (Finn J).
} 
This single question of financial consumer trust in the investment chain should determine all future policy development and implementation. This includes financial literacy (presently the role of ASIC), the future of financial services and financial products provision. Capital markets for SME's to increase industrial productivity and skilled employment, retirement incomes, and Australia's future as a world financial centre substantially rely on it.

\subsection{Retail Financial Advice - Simple Principles Subverted}

The statutory best interest duty in financial advice is prescriptive, ${ }^{81}$ including seven measures, and requires an appropriateness test for retail clients. ${ }^{82}$ These are 'highly relevant to the Court's assessment of compliance with the best interest duty'. ${ }^{83}$ They add to concepts of fiduciary duty in the same case, perhaps even subsuming them. ${ }^{84}$ 'It is likely to be many years before the courts can interpret the content of the duty ... will take many years and many cases before it is clear how the best interest duty operates ${ }^{85} \ldots$ and greatly complicates the existing regime of protections' ${ }^{86}$ 'There does not appear to be any detailed consideration of the provisions that are the subject of this proceeding, ${ }^{87}$ whilst applying Santow principles for breaches of them. ${ }^{88}$ Whilst the origin of the best interest duty is in equity, the statutory duty in retail financial advice is prescriptive and procedural. It may act to reduce or eliminate client equitable remedies.

\footnotetext{
${ }^{81}$ Corporations Amendment (Further Future of Financial Advice Measures) Act 2012 (Cth) s 961B; Corporations Act 2011 (Cth) s 961B(1).

${ }^{82}$ Corporations Amendment (Further Future of Financial Advice Measures) Act 2012 (Cth) s 961G.

${ }^{83}$ ASIC, Re NSG Services Pty Ltd [2017] FCA 345 [18] (Moshinsky J).

${ }^{84}$ Donald (n 9) 142.

${ }^{85}$ Corones and Galloway (n 60) 5.

${ }^{86}$ Ibid 9.

${ }^{87}$ ASIC, Re NSG Services Pty Ltd [2017] FCA 345 [30] (Moshinsky J).

${ }^{88}$ ASIC, Re Golden Financial Group Pty Ltd (formerly NSG Services Pty Ltd) v Golden Financial Group Pty Ltd (No 2) [2017] FCA 1267 [18] (Moshinsky J).
} 
$[T]$ he statutory best interest provision is a long way from what equity understands the 'best interest' concept to mean, on even the narrowest view of that understanding. ... The statutory best interest obligation is expressed as a series of steps to be undertaken, not as an obligation to prefer the client's interest over the firm's or to avoid the situations of conflict or collateral damage that fiduciary law proscribes ... [and is] a significant departure from the best interest obligations that apply in equity to financial advisers. ${ }^{89}$

It is process driven, not outcome driven, provides a safe haven for advisers, ${ }^{90}$ does not fulfil its original policy objectives of statutory fiduciary duty and therefore does not meet community expectations of what the law should mean. These include fiduciary obligations of undivided loyalty of financial and corporate advisers to their clients, and restorative remedies for breach. It further entrenches the doctrine of prioritisation over prohibition. '[I]t may operate to limit existing duties of financial advisers ... apparently contrary to the intention of the post-GFC reforms'. ${ }^{91}$ Subsequent testing in 2017 provides the proof: $100 \%$ of advisers in the sample relied on the statutory safe harbour provision. $75 \%$ of those advisers claiming reliance on it did not comply with their statutory best interest duty with $10 \%$ leaving their client in a worse financial position. ${ }^{92}$ This is damning evidence of the subsuming of general law fiduciary obligation by compromised statute. Thus, expectations of fiduciary obligation create a false sense of security which is not met in practice. They arise from the politicisation of the debate: it is a sop, reflected in parliamentary commentary of the time.

\footnotetext{
${ }^{89}$ Pamela F Hanrahan, 'The relationship between equitable and statutory "best interests" obligations in financial services law' (2013) 46(1) Journal of Equity 7 [V].

${ }^{90}$ Corporations Act 2001 (Cth) s 961B(2)(a)-(g).

${ }^{91}$ Hanrahan (n 89).

92 ASIC, Financial advice: Vertically integrated institutions and conflicts of interest (Report 562, January 2018) [151]-[152].
} 
Accretive statutory change has bizarre results:

[T] he new law applies to some financial services firms who are not fiduciaries with respect to the giving of that advice at general law. However, because of the narrow definition of retail client, many financial advisers who are fiduciaries (for example, the advisers in Wingecarribee $^{93}$ and Bathurst ${ }^{94}$ are not subject to the new law. ${ }^{95}$

\subsection{Financial Advice - Fiduciary Duty to Wholesale Clients with Retail Financial Literacy Competencies}

'Abandon all hope, ye who enter here'. ${ }^{96}$ Wingecarribee Shire Council and other Australian local authorities, "Wingecarribee" 97 and their compatriots in the UK and the US passed through these gates of hell. They suffered losses arising out of their acquisition of synthetic ${ }^{98}$ Collateralised Debt Obligations (CDO) and Credit Default Swaps (CDS), collectively (Dante Notes). ${ }^{99}$

'These products took hundreds of closely typed legally dense pages to document'. ${ }^{100}$ 'A professional, in Grange's position, does not discharge any duty of disclosure or adequately explain a complex transaction merely by giving its client a copy of voluminous documentation and inviting

\footnotetext{
${ }^{93}$ See (n 97).

${ }^{94}$ See (n 123).

${ }^{95}$ Hanrahan (n 89).

${ }^{96}$ Allen Mandelbaum (trans), The divine comedy of Dante Alighieri: Inferno (Bantam Books, 1980).

${ }^{97}$ Wingecarribee Shire Council v Lehman Brothers Australia Ltd (in Liq) [2012] FCA 1028 (Rares J).

${ }^{98}$ Synthetic means the arranging bank does not incur credit exposure.

${ }^{99}$ Lehman Brothers Holdings Inc v City of Swan [2010] HCA 11. These products were sold by Lehman Bros Australia Ltd (Grange Securities Ltd) as adviser. Other advisers selling similar financial products included ABN Amro, Westpac, ANZ, Macquarie Financial Services, Local Government Financial Services, and Commonwealth Bank: Wingecarribee Shire Council v Lehman Brothers Australia Ltd (in Liq) [2012] FCA 1028 [1109] (Rares J).

${ }^{100}$ Wingecarribee Shire Council v Lehman Brothers Australia Ltd (in Liq) [2012] FCA 1028 [3] (Rares J).
} 
the client to look at it, unaided by the professional... ${ }^{101}$ Grange, on inquiry was 'hardly candid' about its remuneration, and its answers were 'calculated to mislead and deceive'. ${ }^{102}$

I do not accept Grange's characterisation of its mere references in its selling materials to other documents that contained the full terms and conditions, including risk disclosures, as an attempt to provide the Councils, as clients, any substantive assistance to understand the underlying issues that may have affected the Councils' investment decision-making. These documents were of a 'byzantine', or as Lord Mance said 'purgatorial' complexity. ${ }^{103}$... Grange had an obligation to make a full and accurate disclosure of its interest in the transaction and all that Grange knew with respect to the product, concealing nothing that might conceivably be regarded as relevant to the making of the investment decision. ${ }^{104}$

None of the Councils had officers with any significant experience in financial products of this complexity. The Councils may have statutory typology of wholesale investors, but decision makers, drawn from the community, had retail financial literacy competencies. ${ }^{105}$ The Dante Notes were also the subject of litigation in the UK and the US. In the UK, the noteholders were given priority to collateral. ${ }^{106}$ In the US the result was the opposite, with the issuer having priority. ${ }^{107}$ The result being:

${ }^{101}$ Ibid [340].

102 Ibid [945].

${ }^{103}$ Ibid [118] (Rares J); citing Belmont Park Investments Pty Ltd v BNY Corporate Trustee Services Ltd [2012]1 AC (UK) 383429 [138].

${ }^{104}$ Ibid [728] (Rares J) citing Daly v Sydney Stock Exchange Ltd [1986] HCA 25.

${ }^{105}$ Grange promoted itself as a financial adviser with specific expertise in local government capital management, advising 85 Councils in New South Wales, 40 in Victoria, and 12 in Western Australia. Local government was a vertical in marketing parlance. Rares J in Wingecarribee Shire Council v Lehman Brothers Australia Ltd (in Liq) [2012] FCA 1028 [32] noted that Grange asserted 'a detailed understanding of the local government market that was unmatched in the financial markets'.

${ }^{106}$ Perpetual Trustee Co Ltd v BNY Corporate Services Ltd [2012] 1 AC (UK) 383.

${ }^{107}$ In re Lehman Bros Holdings Inc 422 BR (USA) 407 (2010). 
[A]s a result of certain conflicting claims and on-going legal proceedings, no distributions can be made to the holders of the Notes at this time $\ldots{ }^{108}$ It will be some time before the United States Courts decide whether to follow the decision of the Supreme Court of the United Kingdom... ${ }^{109}$

'This legal uncertainty' ${ }^{110}$ compounded the decision of the trustee to not make a distribution of collateral to the noteholders. The Federal Court (FCA) approved a settlement for the Councils in December 2015.

The central feature of these legal relationships was a contract, the terms of which did not qualify the fiduciary character of the relationship, equity superimposing fiduciary obligations as an incidence of the relationship. 'Indeed, the equitable remedies for a failure to discharge a fiduciary obligation may be greater than those available in the contract'. ${ }^{111}$ Pointing to the need for statutory reform:

Grange had engaged in deceptive and misleading conduct contrary to what is now a plethora of pointlessly technical and befuddling statutory provisions scattered over many Acts in defined situations. The repealed, simple and comprehensive s 52 of the Trade Practices Act 1974 (Cth) that prohibited corporations engaging in misleading or deceptive conduct in trade or commerce has been done away with by a morass of dense, difficult to understand legislation. Those Acts, that now deal with misleading and deceptive conduct, apply differently depending on distinctions such as whether the alleged misleading conduct is in relation to a 'financial product or a financial service', ${ }^{112}$ or 'financial services'. ${ }^{113}$ Those apparently simple terms are nothing of the sort. A 'financial product' is defined in mind-boggling detail in 7 pages of small type ${ }^{114}$ while a 'financial service' takes another 6 pages to be defined. ${ }^{115}$ The ASIC Act only takes about

\footnotetext{
108 Wingecarribee Shire Council v Lehman Brothers Australia Ltd (in Liq) [2012] FCA 1028 [834] (Rares J).

${ }^{109}$ Ibid [839].

${ }^{110}$ Ibid [841].

${ }^{111}$ Ibid [729]-[730].

${ }^{112}$ Corporations Act 2001 (Cth) s 1041H(1).

113 Australian Securities and Investment Commission Act 2001 (Cth) s 12DA(1).

${ }^{114}$ Corporations Act 2001 (Cth) pt 7.1 div 3.

${ }^{115}$ Ibid pt $7.1 \operatorname{div} 4$.
} 
4 pages to define 'financial service'. ${ }^{116}$ Obviously, there are differences in what each of these Acts and definitions cover - but why? The cost to the community, business, the parties, and their lawyers, and the time for courts to work out which law applies have no rational or legal justification. ${ }^{117}$

Quite so: uncertainty continues: '[T]he application of the provisions defining financial products and financial services in this [Corporations Act] and other acts is often the cause of unnecessary distraction and confusion..., 118

Wingecarribee also pointed to another statutory reform need; there is no prudential supervision of Australian NBFEs other than insurance and superannuation entities. ${ }^{119}$ Grange could not meet its obligations to the Councils.

Dante notes, on Grange's admission, were

suitable only for financial institutions and highly sophisticated professional investors who are capable of understanding ... and who can absorb a substantial or total loss of principal. The Term Sheet is not intended for distribution to, or use by, private customers ... such as the Councils. ${ }^{120}$

What is the distinction between a financial product seller and the provision of financial product

${ }^{116}$ Australian Securities and Investment Commission Act 2001 (Cth) s 12BAB.

${ }^{117}$ Wingecarribee Shire Council v Lehman Brothers Australia Ltd (in Liq) [2012] FCA 1028 Summary 3 (Rares J).

${ }^{118}$ Australian Securities and Investments Commission v Davidof [2017] FCA 658 [4] (Lee J).

${ }^{119}$ Grange was undercapitalised and unable to operate a secondary market for its clients. The Councils were deprived of liquidity in these investments. Grange did not inform its clients of this problem. Undisclosed, Grange controlled the secondary market and certain related party fee structures from which it was able to derive margins. The result, as Rares J noted in Wingecarribee Shire Council v Lehman Brothers Australia Ltd (in Liq) [2012] FCA 1028, the products were 'risky, illiquid, and if sold, might realise far less than their face value, but also that Grange was conscious that the trust its uninformed Council clients had placed in it was being used to Grange's advantage'.

${ }^{120}$ Ibid [339]-[340]. 
advice? ${ }^{121}$ This question arises constantly in NBFE financial product and financial advice markets for all typologies of investors. Peer professional opinion on this distinction is neither universal nor consistent. ${ }^{122}$ A redefinition of Corporations Act investor typology is needed.

Bathurst ${ }^{123}$ was a similar case, being a triumph of promotion over the prudent investment of public funds. 'Rembrandt was a grotesquely complicated product'. ${ }^{124}$

\subsection{Expectations - Failures of Fiduciaries in Financial Advice - Contracting Out}

Unlike Wingecarribee and Bathurst, where fiduciary relationships existed, Citigroup ${ }^{125}$ demonstrated it is possible in Australia to contract out of fiduciary responsibility: it can be extinguished.

[C]laims of conflict of interest and duty and breach of s 912A(1)(aa) depended on the existence of a fiduciary relationship ... the claims failed because the letter of engagement under which Toll retained Citigroup as its adviser specifically excluded the existence of such a relationship. The Court held that the law does not prevent an investment bank from contracting out of a fiduciary capacity; whether it should be able to do so is a matter for the legislature, not the courts. ${ }^{126}$

${ }^{121}$ Lesa Bransgrove, 'Case Note: Wingecarribee Shire Council v Lehman Brothers Australia Ltd (in liq) [2012] FCA 1028' (2013) 24 Journal of Banking and Finance Law and Practice 52 [65].

${ }^{122}$ Ibid citing Civil Liability Act 2002 (NSW) s 5O(1) which 'excluded liability for negligence for acting in a manner that at the relevant time was widely accepted by peer professional opinion as competent practice'.

${ }^{123}$ ABN Amro Bank NV v Bathurst Regional Council [2014] FCAFC 65 (Jacobson, Gilmour and Gordon JJ).

${ }^{124}$ These notes were sold by ABN Amro to Local Government Financial Services (LGFS) which in turn marketed these notes to 13 local government authorities in New South Wales. See ABN Amro Bank NV $v$ Bathurst Regional Council [2014] FCAFC 65 [1082] (Jacobson, Gilmour and Gordon JJ).

${ }^{125}$ ASIC v Citigroup Global Markets Limited (ACN 113 114832)(No 4) [2007] FCA 963 (Jacobsen J).

${ }^{126}$ Ibid [7]. 
Claims of misleading and deceptive conduct and unconscionable conduct ${ }^{127}$ failed for similar reasons. Thus, equitable remediation applied in Wingecarribee and Bathurst could not be achieved.

The 'relationship between the client and the investment bank engaged to advise on a takeover is fiduciary in character', ${ }^{128}$ but 'investment banks have developed contractual techniques to modify or displace fiduciary obligations'. ${ }^{129}$

The critical matter in the end is the role that the alleged fiduciary has, or should be taken to have, in the relationship. It must so implicate that party in the other's affairs or so align him with the protection or advancement of that other's interest that foundation exists for the 'fiduciary expectation'. ${ }^{130}$

'Should be taken to have' is the key to the mismatch between community expectation and practice, not satisfactorily addressed by the Australian legislature or in the trust statutes.

\subsection{Failure to Inquire - Financial Advice - Looking the Other Way}

Opes Prime ${ }^{131}$ and a related entity, Leveraged Capital Pty Ltd, entered into Securities Lending Agreements (SLAs) with their respective clients. ${ }^{132}$ This was one of many cases involving conduct

${ }^{127}$ Corporations Act 2001 (Cth) s 1043H; Australian Securities and Investments Commission Act 2001 (Cth) ss $12 \mathrm{DA}, 12 \mathrm{CA}$.

${ }^{128}$ ASIC v Citigroup Global Markets Limited (ACN 113 114832)(No 4) [2007] FCA 963 [265] Jacobsen J citing Tuch (n 13).

${ }^{129}$ Ibid [267].

${ }^{130}$ Ibid [274] (Jacobsen J) citing Finn, 'The Fiduciary Principle' (n 3).

${ }^{131}$ Lindholm, in the matter of Opes Prime Stockbroking Limited (Administrators appointed) (Receivers and Managers appointed) [2008] FCA 1425 VID 245 [2] (Finkelstein J).

${ }^{132}$ As Finkelstein J noted in Lindholm, in the matter of Opes Prime Stockbroking Limited (Administrators appointed) (Receivers and Managers appointed) [2008] FCA 1425, this SLA was based on the 'standard form Australian Master Securities Lending Agreement (AMSLA) ... which in turn was an adaptation, for Australian purposes, of the standard form Overseas Securities Lending Agreement'. (Now the Global Master Securities Lending Agreement published by the International Securities 
by so-called margin lenders where title to the underlying assets passed to the funding banks, often without the knowledge of the investors, many of whom were longstanding clients. ${ }^{133}$ Imobilari Pty Ltd $v$ Opes Prime ${ }^{134}$ sought to make 'the banks legally liable for the allegedly misleading conduct engaged in by Opes in connection with share lending transactions entered into with investors'. ${ }^{135}$ Banks being knowingly concerned that Opes made misleading representation to investors that they retained the beneficial interests in the loaned shares could result in equitable ${ }^{136}$ and statutory liability. ${ }^{137}$ However, the 'elements of an express trust (intent, object of the trust, and beneficiary) were absent'. ${ }^{138}$

Knowledge, being heavily nuanced and 'not explicitly settled by the High Court', ${ }^{139}$ is nonetheless to be applied in this case as 'knowledge of facts that would put an honest and reasonable person on notice (but not merely inquiry) of a real and not remote risk that the

Lending Association). See also Beconwood Securities Pty Ltd v Australia and New Zealand Banking Group Pty Ltd [2008] FCA 594.

${ }^{133}$ Primebroker Securities Limited v Christopher John Scott [2015] VSC No S CI 2013 4962; SC Capital Pty Ltd $v$ Primebroker Securities Limited (in liquidation) (receivers and managers appointed) SCV [2008] SCV 10548 (Efthim AJ).

${ }^{134}$ Imobilari Pty Ltd v Opes Prime Stockbroking Ltd [2008] FCA 1920 (Finkelstein J).

${ }^{135}$ Ibid [1].

${ }^{136}$ Barnes $v$ Addy (1874) 9 Ch App 244.

${ }^{137}$ Trade Practices Act 1974 (Cth) ss 52, 75B; Corporations Act 2001 (Cth) ss 79, 1041H; Australian Securities and Investments Commission Act 2001 (Cth) s 12DA. As Finkelstein J noted in Imobilari Pty Ltd v Opes Prime Stockbroking Ltd [2008] FCA 1920 [19], 'Opes misled it [the client] into believing that it was opening a margin lending account (ie entering into share mortgage transactions where it retained beneficial ownership) rather than securities lending accounts (ie entering into straight sales where it gave up all ownership interests) and the bank both knew (or ought to have known) that it was being misled and actively went along with it'.

${ }^{138}$ Imobilari Pty Ltd v Opes Prime Stockbroking Ltd [2008] FCA 1920 [25] (Finkelstein J).

${ }^{139}$ Ibid [27]. 
transfer was in breach of trust or fiduciary duty or involved the misapplication of trust property' $\ldots{ }^{140}$ However, what that formulation means is debatable. ${ }^{141}$

In this, and other similar cases, there were regular commercial interactions between the funding banks (wholesalers) and the intermediaries, like Opes, which were the packagers or retailers of these financial products. Formulated legally,

at best, the allegations would establish that the banks had knowledge of circumstances that would have put an honest and diligent person on inquiry. Or, to put it another way, the banks were negligent in failing to keep aware of what Opes was up to.$^{142}$ It is not an overly speculative leap from the proposition that the banks 'should have made due diligence inquiries' to the conclusion that, perhaps, the banks did make such inquiries from which they would have found out through readily available materials ... what Opes was representing to investors ... ${ }^{143}$ The rejection of a duty of inquiry is effectively the rejection of a negligence standard ... ${ }^{144}$

It should be expected that a diligent bank officer, and their risk committees, based on freely available public information and regular commercial interaction, would have known about the ultimate destination of their funds and the terms on which they were being deployed. A diligent financial institution should have studied the AMSLA, being very complicated commercial documents. Looking the other way should not excuse liability. Neither should overt conflicts of interest between NBFE director obligations to their clients and contractual obligations to the banks.

\subsection{Disclosure - An International Problem}

Market based regulatory systems rely heavily on disclosure, including disclosure of conflicts of

\footnotetext{
${ }^{140}$ Ibid.

${ }^{141}$ Ibid [28].

${ }^{142}$ Ibid [33].

${ }^{143}$ Ibid [38].

${ }^{144}$ Ibid [28].
} 
interest. 'Such disclosure is worse than useless if it is not comprehensive'. ${ }^{145}$ 'The belief that the best approach to information asymmetry is the provision of additional data ... [is] acceptable if accompanied by full, even if largely incomprehensible, disclosure', ${ }^{146}$ leads to documentation complexities under the acceptable guise of transparency which hide the narrative required to make sound investment decisions.

Disclosure documents often follow legal form rather than economic substance focussed on the sustainability of business models. This has been a particular problem in non-prudentially regulated Managed Investment Schemes (MIS) in Australia and the UK which do not have US style Management Discussion \& Analysis (MD\&A) sections in their offer documents which must be in plain English.

'Does suitable documentation exist at all'? ${ }^{147}$ Disclosure has become an end in itself, reflecting regulation of market behaviour through process rather than the primacy of the investor or beneficiary reliant upon trusted financial intermediaries. Regulation is seen 'through the eyes of the industry rather than its customers' ${ }^{148}$ with penalties for 'market abuse rather than customer abuse'. ${ }^{149}$ Disclosure is at best an imperfect tool in a financial consumer market where conflicts of interest are permitted. What financial consumers need is trust generated by long term 'deeper' 150 relationships. This is the European fiduciary-like duty of care tradition, albeit subverted (as in the UK) in recent decades by the advent of product selling and transactional relationships.

\footnotetext{
${ }^{145}$ John Kay, The Kay Review of UK Equity Markets and Long Term Decisions Making (Final Report Department of Business, Innovation and Skills UK, July 2012) 67.

${ }^{146}$ Ibid 35.

${ }^{147}$ Christopher Chen Chao-Hung, 'Product due diligence and the suitability of minibonds: taking the benefit of hindsight' [2011] Singapore Journal of Legal Studies 309, 322.

${ }^{148}$ Kay (n 145) 47.

${ }^{149}$ Ibid.

${ }^{150}$ Ibid 46.
} 


\subsection{Information Asymmetry: Is a Governance Regime based on Disclosure Sufficient Investor Protection?}

Multilayered MIS structures can be complex for all but the most sophisticated and attentive retail investor to understand. ${ }^{151}$ It is 'not uncommon that a MIS invests in another MIS to gain exposure to underlying assets in a cost effective manner (eg a retail feeder fund investing in wholesale funds that have greater economies of scale. It is therefore not unsuitable for retail investors' ${ }^{152}$ Lack of product understanding also extends to financial advisers, wealth managers, directors of MIS and trustees of APRA regulated superannuation entities and self-managed superannuation fund trustees. In the US, lack of financial product knowledge by the fund manager has required regulatory intervention.

One of the problems in disclosure is how to report underlying assets in multilayered structures, especially in foreign jurisdictions, where a custodian holds the assets and where there is constant asset turnover. The ASIC Act and the Corporations Act previously imposed restrictions on the investment strategy of registered MIS. These restrictions were removed to allow diversification provided that the investments were not made for the purposes of avoiding regulation. The removal of this restriction facilitated fraudulent behaviour in two Trio MIS in 2009. ${ }^{153}$

Australia is not unique in suffering from systemic creeping corruption arising from disclosure limitations. In Australia, how is complete disclosure of economic rather than transactional interest to be enforced where there is no legal obligation to do so? Where there is no interest in it by the parties concerned? 'It is necessary to shift legislator's attention from ex post

\footnotetext{
${ }^{151}$ Senate, PJC, Parliament of Australia, Inquiry into the collapse of Trio Capital (2012) 31.

${ }^{152}$ Ibid.

${ }^{153}$ Ibid Committee Hansard (6 September 2011), xxiv, 75 (Greg Medcraft).
} 
enforcement to ex ante supervised self-regulatory regime'. ${ }^{154}$ Proactive disclosure (including potential conflicts of interest) should apply to all in the investment chain.

\subsection{Disclosure in Comparative Jurisdictions}

In Germany, retail investors are treated as financial consumers rather than capital providers.

Disclosure must be in a 'comprehensible form'. ${ }^{155}$ It is not information that is being consumed, but confidence in the person providing the disclosures. ${ }^{156}$ This policy widens disclosure obligations to investors enlivening its culpa in contrahendo doctrine with statutory 'very detailed level of codification'. ${ }^{157}$ Law reform designed to unlock retail investor savings, relying on their financial literacy (but without formal investor education) and on advice, also required liberalisation of financial products 'easily understood by the "average retail investor"'.${ }^{158}$ German law differs substantively from Australian law in these respects.

\subsection{Related Party Transactions, Conflicts of Interest and Duty}

Related parties, conflicts of interest and duty are common in MIS. The empirical analysis suggests that related party transactions have predictive veracity to conflicts of interest, failures in disclosure, dishonesty and breaches of statutory and fiduciary duties.

${ }^{154}$ Dirk Zetzsche, 'Hidden Ownership in Europe: BAFin's Decision in Schaeffler v Continental' (2009) 10 European Business Organization Review 115, 146.

${ }^{155}$ Niamh Moloney, 'Building a Retail Investment Culture through Law: The 2004 Markets in Financial Instruments Directive' (2005) 6 European Business Organization Law Review 341, 386.

${ }^{156}$ Susanne Kalss, 'Civil Law Protection of Investors in Austria - A Situation Report from Amidst a Wave of Investor Law Suits' (2012) 13 European Business Organization Law Review 211, 225.

${ }^{157}$ Sebastian Barry and Hannes Bracht, 'The Implementation of the MiFID into the WpHG' (2008) 9(9) German Law Journal 1177, 1185.

${ }^{158}$ Moloney, 'Building a Retail Investment Culture through Law' (n 155) 352. 
Recusal from a meeting is common practice in Australia where there are related parties and conflicts of interest. Jones $v$ Invion ${ }^{159}$ makes a mockery of such practices. Recusal and mere disclosure are not sufficient. ${ }^{160}$ '[C]ould hardly be considered arms-length ... It rather suggests the contrary, that it was a collegial or corporate or complicit endeavour'. ${ }^{161}$

The directors acting 'in concert ${ }^{\text {' }}$ ' did not confine themselves to improper board procedures, but were also aware of shareholder disquiet about corporate governance and their likely rejection of approval for remuneration in the form of performance rights. For these directors, a corporate governance standard which relied upon unminuted oral agreement several years previously whereby 'any of them, acting alone, could exercise the authority of the Board' ${ }^{163}$ was sufficient. There could be 'no suggestion that the non-executive directors were fully informed'. ${ }^{164}$ In fact, they were incorrectly informed.

Dishonest behaviour may in some circumstances have an honest explanation. Relief from liability requires a positive finding of honesty, not available to these Invion directors. These

${ }^{159}$ Jones v Invion Ltd [2015] QCA 100 (McMurdo P and Philippides JA and Peter Lyons J): 'The directors acted dishonestly, and breach of their duties, when, without authority, each of them purported on behalf of the first respondent, to vary the termination provisions of the contracts or consultancy agreement of another of them ... [and] did not tell the full board of the changes. ... This "unjust enrichment" was [stated to be]: the "conventional" way of transacting such business within the company ... the directors by-passed the Board because they surmised the Board would not agree. Consistently, they did not disclose to the Board what they had done. ... The [appellant] directors were patently obliged to inform their fellow [non-executive] directors of those matters, especially where the solvency of the [first respondent] was in doubt, the contingent liability was so substantial, and the [appellants] were themselves the potential beneficiaries'.

${ }^{160}$ Fitzsimmons $v$ The Queen (1997) 23 ACSR 355 cited in Rosemary Langford, The Bona Fide Fiduciary Loyalty of Australian Company Directors (PhD Thesis, Monash University, 2013) 314 [3.7.4].

${ }^{161}$ Jones v Invion Ltd [2015] QCA 100 [57] (McMurdo P and Philippides JA and Peter Lyons J).

${ }^{162}$ Jones v Invion Ltd [2015] QCA 100 [14] (McMurdo P and Philippides JA and Peter Lyons J).

${ }^{163}$ Ibid.

${ }^{164}$ Ibid. 
directors 'owed fiduciary duties to the company of which they were directors, to avoid conflict of duty and interest and not to take advantage of their position to secure a personal benefit. ${ }^{165}$ They did not exercise reasonable care and diligence, ${ }^{166}$ or act in good faith, ${ }^{167}$ and used their 'position to gain personal advantage'. ${ }^{168}$

In Trilogy $v$ Sullivan: ${ }^{169}$

This is a tale of a rapacious Gold Coast property developer with grandiose plans, a compliant and obliging valuer who lacked independence, and a responsible entity of a managed investment scheme the officers of which appeared unable or unwilling to say 'no' to the developer, or to exercise appropriate care and diligence... [T] he scheme and its members were left significantly out of pocket. ${ }^{170}$

Some directors "well knew that the proposal was not supported by any remotely acceptable "as is" valuation..., $^{171}$

Another Gold Coast related party case, Managed Investments: ${ }^{172}$

The insouciant attitude of the defendants to this misuse of money intended to be used for PIF's investors beggars belief. ${ }^{173}$ [T] hose controlling responsible entities ... must act with honesty and competence and remember at all times that they are dealing with other people's money. ${ }^{174}$

In a consolidating NBFE market with a limited supply of knowledgeable directors, trustees, and

165 Ibid.

${ }^{166}$ Corporations Act 2001 (Cth) s 180.

${ }^{167}$ Ibid s 181.

${ }^{168}$ Ibid s 182.

${ }^{169}$ Trilogy Funds Management Limited v Sullivan (No 2) [2015] FCA 1452 (Wigney J).

${ }^{170}$ Ibid [1].

${ }^{171}$ Ibid [612].

${ }^{172}$ ASIC v Managed Investments Ltd (No 10) [2017] QSC 96 (Douglas J).

${ }^{173}$ Ibid [233] (Douglas J) describing the conduct of directors of the RE of the Premium Income Fund.

${ }^{174}$ Ibid [232d]. 
professional advisers, it is inevitable that their fiduciary duties be compromised by conflicts of interest, actual or potential. ${ }^{175}$ Commercial practice has been to establish Chinese Walls. If they serve a useful or proper purpose, their scope is necessarily limited by the permeable nature of walls, originally designed to quarantine information from persons within one organisation. Where the proper exercise of fiduciary duty extends to decisions about fellow directors and trustees, including litigation, Chinese Walls are unlikely to suffice. ${ }^{176}$

In Australia, many public offer superannuation entities (industry funds) have representative directors from employers and employees. Originally with equal representation, ${ }^{177}$ now subject to contested legislative change, these appointments do lead to conflicts of interest. There are no differences in the SIS Act in relation to responsibilities as directors of the trustee notwithstanding differences in the manner of the appointments. ${ }^{178}$ This conflict appears to be an integral part of the SIS legislation.

The potential for conflict by virtue of their appointment alone does not mean that there is a conflict of the sort that means a director is in breach of a fiduciary duty. There must be something more that shows that there is in fact a conflict of duty between the interests of the directors of a trustee of a fund. This must be determined by reference to the circumstances and not by references to a formula or recitation of principle. ${ }^{179}$

\footnotetext{
${ }^{175}$ Nuncio D'Angelo, 'Private equity investing by financial institutions: Navigating hidden reefs in treacherous waters' (2003) 31 Australian Business Law Review 325.

${ }^{176}$ Australian Executor Trustees Ltd v Provident Capital Ltd, in the matter of Provident Capital Ltd (receivers and managers appointed) (in liq) [2013] FCA 1461 (Rares J).

177 Superannuation Industry (Supervision) Act 1993 (Cth) s 89.

${ }^{178}$ Superannuation Industry (Supervision) Act 1993 (Cth) s 10(1).

179 VBN and Australian Prudential Regulation Authority [2006] AATA 710 [547] (S A Forgie V-P and B H Pascoe).
} 
Conflicts of interest may be ameliorated, ${ }^{180}$ but only in circumstances specifically to the appointment as representative director. ${ }^{181}$ Naively, '[a] further safeguard to the protection of member's interests is to rely on a well-informed membership with the right to participate in managing the affairs of their fund'. ${ }^{182}$

The influence of Registered Organisations in the investment economy is driven by compulsory superannuation outsourced to the private sector. It is a recent phenomenon, its significance under-appreciated. This significance has not attracted the regulatory attention it deserves: until Heydon: ${ }^{183}$

the existing criminal laws do not appear to operate as much of a deterrent to employers giving and union officials taking bribes, secret commissions and other lawful payments ... History appears to be repeating itself $\ldots{ }^{184}$ It is a recurring problem.... it is insidious. It is immensely damaging ... longstanding $\ldots$ clandestine $\ldots{ }^{185}$

Heydon identified unhealthy culture facilitating corrupting benefits of various forms as related party transactions as cultural problems 'antithetical to the rule of law ... if unchecked, the culture comes to taint and impact the wider society'. ${ }^{186}$ There are 'significant issues about the scope and effectiveness of existing law concerning the duties of union officers ... existing law appears to have

${ }^{180}$ Sargeant v National Westminster Bank Plc (1990) 61 P \& CR 518 cited in VBN and Australian Prudential Regulation Authority [2006] AATA 710 [535] (S A Forgie V-P and B H Pascoe).

${ }^{181}$ VBN and Australian Prudential Regulation Authority [2006] AATA 710 [535] (S A Forgie V-P and B H Pascoe).

${ }^{182}$ Commonwealth, Hansard, Superannuation Industry (Supervision) Bill, House of Representatives, 27 May 1993, 1101 [1] (Paul Keating, Treasurer).

${ }^{183}$ Heydon (n 3).

${ }^{184} 1982$ Winneke Royal Commission; 1992 Gyles Royal Commission; 2003 Cole Royal Commission;

Commonwealth, Royal Commission into Trade Union Governance and Corruption (Final Report) (n 15) ch 4 29-30 (Commissioner Heydon).

${ }^{185}$ Commonwealth (n 15) ch 4 [58].

${ }^{186}$ Ibid ch 410. 
done nothing to prevent the apparent egregious misappropriations of ... assets' ${ }^{187}$ Utterly derisory ... manifestly inadequate... ${ }^{188}$ Systemic failure of regulation to prevent improper conduct by officers of registered organisations: members of the public and the organisations concerned surely would agree - how can this be?

Recent examples of financial misconduct within registered organisations have demonstrated that the existing regulatory framework is not sufficient to provide members of registered organisations with confidence that the management of registered organisations is accountable and transparent and that their membership contributions are being used for proper purposes. ${ }^{189}$

'Sunlight is said to be the best of disinfectants ...' 190

\footnotetext{
${ }^{187}$ Ibid ch 32.
}

${ }^{188}$ Ibid ch 389.

${ }^{189}$ Revised Explanatory Memorandum, Fair Work (Registered Organisations) Amendment Bill 2014.

${ }^{190}$ Polina Demina, 'Broker-Dealers and Investment Advisers: A Behavioural Economics Analysis of Competing Suggestions for Reform' (2014) 113 Michigan Law Review 440 citing Louis D Brandeis, Other Peoples' Money and How the Bankers Use It (F A Stokes, 1914). 


\section{The Empirical Evidence, Cause and Effect 1981-2018 Systemic Failures in Law and their Empirical Effects}

Many reform areas have lagged for ... a lack of a specific enough analytical framework and appropriate data with which to evaluate the possible costs and benefits of various regulations and their interactions, making reform steps consequently unclear; and a lack of practical methods of implementation... ${ }^{191}$

This research provides that analytical framework. It converts unstructured text to a quantitative data set on which future policy can be based. It provides insightful data in several dimensions which are indicators and tools to predict ex ante investment legal risk, hitherto ex post. This framework identifies previously unknown factors and the basis for strategic and tactical reform.

\subsection{Non-Bank Financial Entities (NBFEs)}

This empirical analysis quantifies the financial losses incurred by investors in the Australian NBFE sector through the period described in Chapter 2. Loss is defined as complete or partial loss of funds, impairment, or risk of complete or partial loss. Dates of these failures are estimated from the date of administrator or provisional liquidator appointments or the date of the first court judgment (including directions hearings). Malfeasance may have commenced at earlier dates but remained undiscovered or unreported. The sample includes failed NBFEs from 1981 to 2018, but excludes those frozen as a result of the GFC in 2008/9 and subsequently unfrozen.

The categories of NBFE in the sample include: financial products and financial services conglomerates; investment banks, government rescued entities; insurance entities; hedge funds; Managed Investment Schemes (MIS) and debenture trusts (real estate); MIS (forestry and agribusiness); companies with similar agribusiness models to MIS; MIS (infrastructure); securities brokers and securities leveraged lending; securities trading platforms; wealth, financial planning

\footnotetext{
${ }^{191}$ Stijn Claessens and Laura Kodres, 'The Regulatory Responses to the Global Financial Crisis: Some uncomfortable questions' (Working Paper No 14/46, International Monetary Fund, March 2014) 4.
} 
and funds management firms and workers entitlement funds (being exempt MIS). NBFEs in the Australian superannuation industry include industry funds, retail funds, corporate funds, and SMSFs. There is a small (by number) government superannuation sector. ${ }^{192}$

\subsection{Methodology}

'[I]n Australia, comprehensive case data regarding filed cases or settled cases are not available'. ${ }^{193}$ A review of published senior court judgments ${ }^{194}$ of NBFE cases $(n=320$, of which 199 have authoritative primary empirical data) 1981-2018 (a 38 year investment period) forms the basis of this analysis. Many cases involved multiple proceedings. There is no comprehensive electronic search system which captures the reasons for these senior court judgments and reliance on case catchwords can be misleading. A reading of the judgments is required. These hand-collected data from the content of the judgments are supplemented by data sourced from other authoritative sources including Royal Commissions, Parliamentary Inquiries, ASIC and APRA documents, liquidators' reports, and selected third party publications. Magistrates, District and County Court judgments are mostly excluded from the sample. Many of these are professionally unreported. The sample excludes unreported private ex-curial proceedings but does include cases where enforceable undertakings are an outcome of civil proceedings. Cases are grouped where related parties appear in similar judgments, but separated where a related party entity is involved in proceedings involving different issues of law or a different business type. For instance, a RE of one or more operational MIS may have a related party finance company. These are treated as separate cases, but multiple MIS with the same RE are treated as one case. This typology does not diminish the reporting of

\footnotetext{
${ }^{192}$ Eg Future Fund, Queensland Investment Corporation.

${ }^{193}$ Jenifer Varzaly, 'The Enforcement of Directors Duties in Australia: An Empirical Analysis' (2015) 16 European Business Organization Law Review 281, 300.

${ }^{194}$ HCA, FCAFC, FCA, NSWSC, NSWCA, VSC, VSCA, QSC, QCA, SASC, SASCA, WASC, WASCA.
} There are a very small number from lower courts. 
issues of law in Table 3.22. It does reduce the number of discrete incidences (there are many cases with similar multiple incidences in the same case), but does not reduce the number of investors or the quantum of their losses.

There is a lack of consistency in court judgments in the reporting of empirical data.

Inference is required in some cases. Where there is no reliable primary source, no assumptions have been made. Financial press reports are not sources. So it is likely that the data reported below are underestimates of the true position. Nonetheless, empirical and legal trends are clear. Care has been taken to avoid double counting of empirical data, for instance where a replacement RE becomes trustee for a MIS. The analysis identifies the primary legal issues addressed in the judgments, their legal effect, estimated number of investors and quantum of their losses and impairment, remediation, entities associated with each case, the responsible regulator, date of first reporting, and their legal citation. This data is summarised below. There is no other single holistic authoritative source. The primary data is in spreadsheet format. Much of the remedial data is publicly unreported, some is confidential. What is reported illustrates a low rate of recovery. ${ }^{195}$ This is supported by this analysis with an average $4.24 \%$ recovery or remediation across the sample. There are some exceptions where recovery is significantly higher: these merely serve to emphasise the abysmal rates of recovery elsewhere, demonstrating that Australia's ex post regulatory posture does not serve investors well.

\subsection{Summary of Empirical Data}

The following tables summarise the empirical data by type of NBFE with Tables 3.17 and 3.21 reporting the aggregate data. The tables include the number of NBFEs in the sample, the number for which there is authoritative source data, investor funds lost or at risk of permanent impairment, and the number of investors or beneficiaries adversely impacted. In some cases, for example Table 3.2,

\footnotetext{
${ }^{195}$ Varzaly (n 193) 302. Qualitative research supports this analysis.
} 
government is the sole shareholder notwithstanding that prior to government control, many

thousands of investors have been involved. In some superannuation entities (Table 3.13) a consortium is reported by its membership numbers, not by the number of investor beneficiaries in the consortium funds membership.

\section{TABLE 3.1 Financial Services and Financial Products Conglomerates}

This sample includes vertically integrated multifunction NBFEs.

\begin{tabular}{|l|l|l|l|}
\hline No. NBFEs in sample & $\begin{array}{l}\text { No. NBFEs with } \\
\text { authoritative data } \\
\text { source }\end{array}$ & $\begin{array}{l}\text { Funds lost or } \\
\text { permanently } \\
\text { impaired (AUD mill) }\end{array}$ & $\begin{array}{l}\text { No. investors or } \\
\text { beneficiaries } \\
\text { impacted }\end{array}$ \\
\hline 16 & 15 & 14,731 & 112,634 \\
\hline
\end{tabular}

\section{TABLE 3.2 Government Rescued Financial Entities}

During the sample period, government intervention has resulted in control.

\begin{tabular}{|l|l|l|l|}
\hline No. NBFEs in sample & $\begin{array}{l}\text { No. NBFEs with } \\
\text { authoritative data } \\
\text { source }\end{array}$ & $\begin{array}{l}\text { Funds lost or } \\
\text { permanently } \\
\text { impaired (AUD mill) }\end{array}$ & $\begin{array}{l}\text { No. investors or } \\
\text { beneficiaries } \\
\text { impacted }\end{array}$ \\
\hline 5 & 5 & 6,502 & 7 \\
\hline
\end{tabular}

\section{TABLE 3.3 Insurance Entities}

\begin{tabular}{|l|l|l|l|}
\hline No. NBFEs in sample & $\begin{array}{l}\text { No. NBFEs with } \\
\text { authoritative data } \\
\text { source }\end{array}$ & $\begin{array}{l}\text { Funds lost or } \\
\text { permanently } \\
\text { impaired (AUD mill) }\end{array}$ & $\begin{array}{l}\text { No. investors or } \\
\text { beneficiaries } \\
\text { impacted }\end{array}$ \\
\hline 14 & 6 & 957 & 69,292 \\
\hline
\end{tabular}

\section{TABLE 3.4 Hedge Funds}

Hedge funds are pools of capital, historically lightly regulated, mobile capital. Large quantities of hedge fund capital can rapidly be brought to bear opaquely on specific investment strategies globally. The owners of the capital, the investors, are typically the family offices of high net worth individuals, family trusts, and investment banks. Over time, they were joined by superannuation 
funds, retail investors, local government, and university endowment funds.

\begin{tabular}{|l|l|l|l|}
\hline No. NBFEs in sample & $\begin{array}{l}\text { No. NBFEs with } \\
\text { authoritative data } \\
\text { source }\end{array}$ & $\begin{array}{l}\text { Funds lost or } \\
\text { permanently } \\
\text { impaired (AUD mill) }\end{array}$ & $\begin{array}{l}\text { No. investors or } \\
\text { beneficiaries } \\
\text { impacted }\end{array}$ \\
\hline 4 & 3 & 738 & 1,745 \\
\hline
\end{tabular}

TABLE 3.5 Managed Investment and Debenture Schemes: Real Estate

\begin{tabular}{|l|l|l|l|}
\hline No. NBFEs in sample & $\begin{array}{l}\text { No. NBFEs with } \\
\text { authoritative data } \\
\text { source }\end{array}$ & $\begin{array}{l}\text { Funds lost or } \\
\text { permanently } \\
\text { impaired (AUD mill) }\end{array}$ & $\begin{array}{l}\text { No. investors or } \\
\text { beneficiaries } \\
\text { impacted }\end{array}$ \\
\hline 81 & 56 & 10,423 & 291,517 \\
\hline
\end{tabular}

TABLE 3.6 Managed Investment Schemes: Forestry and Agribusiness

\begin{tabular}{|l|l|l|l|}
\hline No. NBFEs in sample & $\begin{array}{l}\text { No. NBFEs with } \\
\text { authoritative data } \\
\text { source }\end{array}$ & $\begin{array}{l}\text { Funds lost or } \\
\text { permanently } \\
\text { impaired (AUD mill) }\end{array}$ & $\begin{array}{l}\text { No. investors or } \\
\text { beneficiaries } \\
\text { impacted }\end{array}$ \\
\hline 33 & 23 & 6,826 & 169,590 \\
\hline
\end{tabular}

TABLE 3.7 Investment Companies with Similar Business Models

\begin{tabular}{|l|l|l|l|}
\hline No. NBFEs in sample & $\begin{array}{l}\text { No. NBFEs with } \\
\text { authoritative data } \\
\text { source }\end{array}$ & $\begin{array}{l}\text { Funds lost or } \\
\text { permanently } \\
\text { impaired (AUD mill) }\end{array}$ & $\begin{array}{l}\text { No. investors or } \\
\text { beneficiaries } \\
\text { impacted }\end{array}$ \\
\hline 6 & 6 & 178 & 2,324 \\
\hline
\end{tabular}

TABLE 3.8 Managed Investment Schemes: Infrastructure

\begin{tabular}{|l|l|l|l|}
\hline No. NBFEs in sample & $\begin{array}{l}\text { No. NBFEs with } \\
\text { authoritative data } \\
\text { source }\end{array}$ & $\begin{array}{l}\text { Funds lost or } \\
\text { permanently } \\
\text { impaired (AUD mill) }\end{array}$ & $\begin{array}{l}\text { No. investors or } \\
\text { beneficiaries } \\
\text { impacted }\end{array}$ \\
\hline 6 & 2 & 2,924 & 850 \\
\hline
\end{tabular}


TABLE 3.9 Securities Broking and Leveraged Lending

\begin{tabular}{|l|l|l|l|}
\hline No. NBFEs in sample & $\begin{array}{l}\text { No. NBFEs with } \\
\text { authoritative data } \\
\text { source }\end{array}$ & $\begin{array}{l}\text { Funds lost or } \\
\text { permanently } \\
\text { impaired (AUD mill) }\end{array}$ & $\begin{array}{l}\text { No. investors or } \\
\text { beneficiaries } \\
\text { impacted }\end{array}$ \\
\hline 9 & 8 & 1,105 & 2,304 \\
\hline
\end{tabular}

TABLE 3.10 Securities Trading Platforms

\begin{tabular}{|l|l|l|l|}
\hline No. NBFEs in sample & $\begin{array}{l}\text { No. NBFEs with } \\
\text { authoritative data } \\
\text { source }\end{array}$ & $\begin{array}{l}\text { Funds lost or } \\
\text { permanently } \\
\text { impaired (AUD mill) }\end{array}$ & $\begin{array}{l}\text { No. investors or } \\
\text { beneficiaries } \\
\text { impacted }\end{array}$ \\
\hline 18 & 12 & 226 & 5,647 \\
\hline
\end{tabular}

TABLE 3.11 Wealth Management, Financial Planning, and Funds Management

This sector is pervasive, often under-skilled, sometimes conflicted, and has seriously impacted the financial standing of many of its clients.

\begin{tabular}{|l|l|l|l|}
\hline No. NBFEs in sample & $\begin{array}{l}\text { No. NBFEs with } \\
\text { authoritative data } \\
\text { source }\end{array}$ & $\begin{array}{l}\text { Funds lost or } \\
\text { permanently } \\
\text { impaired (AUD mill) }\end{array}$ & $\begin{array}{l}\text { No. investors or } \\
\text { beneficiaries } \\
\text { impacted }\end{array}$ \\
\hline 72 & 43 & 4,018 & 423,741 \\
\hline
\end{tabular}

\section{TABLE 3.12 Retail Superannuation Funds}

\begin{tabular}{|l|l|l|l|}
\hline No. NBFEs in sample & $\begin{array}{l}\text { No. NBFEs with } \\
\text { authoritative data } \\
\text { source }\end{array}$ & $\begin{array}{l}\text { Funds lost or } \\
\text { permanently } \\
\text { impaired (AUD mill) }\end{array}$ & $\begin{array}{l}\text { No. investors or } \\
\text { beneficiaries } \\
\text { impacted }\end{array}$ \\
\hline 3 & 3 & 372.50 & 31,076 \\
\hline
\end{tabular}

\section{TABLE 3.13 Industry Superannuation Funds}

\begin{tabular}{|l|l|l|l|}
\hline No. NBFEs in sample & $\begin{array}{l}\text { No. NBFEs with } \\
\text { authoritative data } \\
\text { source }\end{array}$ & $\begin{array}{l}\text { Funds lost or } \\
\text { permanently } \\
\text { impaired (AUD mill) }\end{array}$ & $\begin{array}{l}\text { No. investors or } \\
\text { beneficiaries } \\
\text { impacted }\end{array}$ \\
\hline 19 & 5 & 2,918 & 291,458 \\
\hline
\end{tabular}




\section{TABLE 3.14 Workers Entitlement Funds (WEFs)}

WEFs are controlled by related party registered organisations, usually structured as exempt MIS.

\begin{tabular}{|l|l|l|l|}
\hline No. NBFEs in sample & $\begin{array}{l}\text { No. NBFEs with } \\
\text { authoritative data } \\
\text { source }\end{array}$ & $\begin{array}{l}\text { Funds lost or } \\
\text { permanently } \\
\text { impaired (AUD mill) }\end{array}$ & $\begin{array}{l}\text { No. investors or } \\
\text { beneficiaries } \\
\text { impacted }\end{array}$ \\
\hline 7 & 2 & 146 & 24,730 \\
\hline
\end{tabular}

TABLE 3.15 Other Superannuation Entities

\begin{tabular}{|l|l|l|l|}
\hline No. NBFEs in sample & $\begin{array}{l}\text { No. NBFEs with } \\
\text { authoritative data } \\
\text { source }\end{array}$ & $\begin{array}{l}\text { Funds lost or } \\
\text { permanently } \\
\text { impaired (AUD mill) }\end{array}$ & $\begin{array}{l}\text { No. investors or } \\
\text { beneficiaries } \\
\text { impacted }\end{array}$ \\
\hline 8 & 3 & 105 & 1,370 \\
\hline
\end{tabular}

TABLE 3.16 Finance Companies

\begin{tabular}{|l|l|l|l|}
\hline No. NBFEs in sample & $\begin{array}{l}\text { No. NBFEs with } \\
\text { authoritative data } \\
\text { source }\end{array}$ & $\begin{array}{l}\text { Funds lost or } \\
\text { permanently } \\
\text { impaired (AUD mill) }\end{array}$ & $\begin{array}{l}\text { No. investors or } \\
\text { beneficiaries } \\
\text { impacted }\end{array}$ \\
\hline 16 & 7 & 81 & 487,323 \\
\hline
\end{tabular}

\section{Other Entities}

Other NBFEs not part of the sample include film schemes, property timeshare schemes, actively managed strata title schemes, contributory mortgage schemes, litigation funders, betting schemes, aged care and retirement accommodation, and management rights. ${ }^{196}$

${ }^{196}$ Alan Jessup, Killing Bambi - Improving the effectiveness and efficiency of the legal and regulatory framework for protection of retail investors investing in collective investment schemes (SJD thesis application to University of Sydney, 2012); Alan Jessup, Managed Investment Schemes (Federation Press, 2012) 30. See also ASIC, 'How to register a managed investment scheme' (26 October 2017) $<$ http://www.asic.gov.au/for-finance-professionals/fund-operators/establishing-and-registering-afund/how-to-register-a-managed-investment-scheme/>. 
TABLE 3.17 Aggregate Data

\begin{tabular}{|l|l|l|l|}
\hline No. NBFEs in sample & $\begin{array}{l}\text { No. NBFEs with } \\
\text { authoritative data } \\
\text { source }\end{array}$ & $\begin{array}{l}\text { Funds lost or } \\
\text { permanently } \\
\text { impaired (AUD mill) }\end{array}$ & $\begin{array}{l}\text { No. investors or } \\
\text { beneficiaries } \\
\text { impacted }\end{array}$ \\
\hline 320 & 199 & 52,251 & $1,915,608$ \\
\hline
\end{tabular}

\subsection{Table of Cases}

This data has been sourced from 199 senior court cases. ${ }^{197}$

\subsection{A National Productivity Issue: the Law Matters}

NBFE investment is largely at the margin, being venture financing not provided by mainstream prudentially regulated banks. Whilst superannuation investment is prudentially regulated, interest group pressure is publicly applied to trustees to deploy capital in favoured ways, sometimes by related parties. Financing at the margin should earn a risk adjusted return. A proxy for the return expected is the ASX long term all accumulation index (ie dividends are reinvested). This is the risk adjusted return NBFE investors should have expected if capital had been successfully deployed in accordance with disclosure documents. That capital has not been successfully deployed in the cases cited. Much has been lost in deadweight costs (on investment and insolvency), with the balance lost, earning zero or considerably less than forecast. These are direct losses only. They do not account for indirect, consequential, and social losses or the increased risk aversion of other investors. Table 3.18 quantifies the adverse economic impact. This data is illustrative - it is not definitive of the complete universe of NBFEs. It relies on extraction of empirical data from the unstructured data sets in the sample. Hitherto, comparative conclusions have been largely anecdotal and ad hoc. Table 3.18 attempts to begin to quantify the social and economic costs of present Australian law.

${ }^{197}$ Millhouse (n 1) app 3. 
TABLE 3.18 Estimated Impact of Cumulative Investor Losses on Australian Productivity ${ }^{198}$

\begin{tabular}{|l|r|}
\hline GDP computation & AUD billion \\
\hline Accumulated investor losses & 52,251 \\
\hline All Ords All Accum Index LT return 15\% & 7,838 \\
\hline Nominal Australian GDP 2016-17 & $1,693,452$ \\
\hline Loss \% nominal GDP & $0.4628 \%$ \\
\hline Nominal Australian GDP growth 2016-17 & $2.00 \%$ \\
\hline Loss \% nominal GDP growth & $23.14 \%$ \\
\hline
\end{tabular}

The aggregate adverse consequences are equivalent to over $0.46 \%$ of $2016-17$ nominal Australian GDP. This capital should have been generating economic activity each and every year since investment up to the date of capital return and subsequent reinvestment. Had the capital been properly deployed in accordance with disclosure documents, it implies that the national economy could have grown $23.14 \%$ faster than it did, driven by entrepreneurial NBFE financing. The essential insight is that the cumulative misallocation of capital in aggregate - the opportunity cost - causes lower economic growth. This is particularly so because NBFE financing is at the margin - it finances projects that would not otherwise occur.

This has considerable economic costs for Australian business. It is a national productivity issue and is a direct result of systemic failures in the Australian regulatory regime. Risk aversion and reluctance to invest in NBFEs is a feature of the present investment landscape. Paucity of marginal sources of capital for ventures leads directly to capital constraints in the more entrepreneurial parts of the economy. It explains the paucity of available collective investment options, the distrust of mandatory superannuation and the preference for direct investment into real property, particularly by Self-Managed Superannuation Funds (SMSFs) and discretionary trusts.

Most investors are in the 25-64 age cohorts (being a 40 year investment period). Losses thus fall disproportionately on them. A large proportion of that potential cohort is limited to direct investment in compulsory non-SMSF superannuation, home mortgage, rental mortgages, and bank

${ }^{198}$ Australian Bureau of Statistics, Key Economic Indicators (Series 1345.0, 2017). 
deposits. By inference, the investing cohort is smaller than the aggregate suggests. The percentage of investors affected in aggregate sets the lower bound which assumes $100 \%$ of the aggregate NBFE investing cohort actually invests. Hence the proportion suffering adverse impacts is likely to be significantly larger than $15.87 \%$.

Much NBFE investing is through discretionary (family) and SMSF trusts, a lower proportion of investors than the aggregate cohort. Many of these operate through custodians or nominees. Many will have multiple investments, multiple investment structures, and will have been exposed in more than one instance. That is why the data is illustrative, not definitive. A definitive empirical data set demands transparency in beneficial ownership. This does not presently exist and cannot necessarily be extracted from the judgments. It also demands analytical resources which only the largest custodians or ASIC and APRA could have. Indeed, it may be beyond human intervention and, should transparency occur, require the use of cognitive, artificially intelligent digital robots to source, analyse, and report on the data. This data uses the number of SMSFs and Australian resident trusts as a proxy — it seeks to do nothing more than provide a basis for assessing the macroeconomic and social impacts. The essential insight is it provides a methodological framework for when transparency of diffuse securities ownership and the application of artificial intelligence in the law allow. 
TABLE 3.19 Percentage of Investing Population Directly Affected ${ }^{199}$

\begin{tabular}{|l|r|r|}
\hline Investing population analysis & male & female \\
\hline Individuals & $4,783,473$ & $4,626,603$ \\
\hline $25-54$ & $1,321,246$ & $1,341,329$ \\
\hline $55-64$ & $6,104,719$ & $5,967,932$ \\
\hline & $12,072,651$ & \\
\hline Total possible investing population & $1,915,608$ & \\
\hline \# Investors lost capital & $15.87 \%$ & \\
\hline \% of total possible investing population & & \\
\hline Corporate investors & 596,517 & \\
\hline \# SMSF's & $1,130,000$ & \\
\hline \# SMSF members & 642,000 & \\
\hline \# Discretionary trusts & $1,238,517$ & \\
\hline Total corporate investing structures & $1,772,000$ & \\
\hline Total estimated members & $1,905,608$ & \\
\hline \# Investors lost capital & $107.54 \%$ & \\
\hline \% of total possible investing population & & \\
\hline
\end{tabular}

If individual discretionary and SMSF trust investors are used as a proxy, the proportion directly affected rises to $107.54 \%$. So the range is $15.87 \%-107.54 \%$. Some investors use multiple structures and some invest personally outside of these structures which accounts for the statistical oddity in the upper bound data. The percentage accorded these investing structures is a proxy for the upper bound.

Reduced propensity for NBFE investment by those not suffering direct losses would further increase this proportion. This implies considerable disruption of the NBFE capital markets. The costs of disruption have been quantified elsewhere with estimates of economic loss having a multiplier of 18 times, much of it attributed to 'unmanaged conflicts of interest' ${ }^{200}$

${ }^{199}$ Central Intelligence Agency, World Factbook (CIA, 2015)

$<$ www.indexmundi.com/australia/age_structure.html $>$; Australian Prudential Regulation Authority, Statistics Annual Superannuation Bulletin (June 2017) 10.

${ }^{200}$ Minouche Shafik, "From "ethical drift" to "ethical lift" - Reversing the tide of misconduct in global financial markets' (Panel Discussion at the Federal Reserve Bank of New York Conference on Reforming Culture and Behaviour in the Financial Services Industry, 20 October 2016) 2. 


\subsection{Hypothesis Testing by Qualitative Research}

Confidential qualitative research interviews have been conducted with senior professional and investment persons $(\mathrm{n}=28)$ in each of Sydney, Melbourne, and Brisbane. Each person was questioned using open ended technique from a prepared list designed to identify problematic issues requiring reform. Table 3.20 summarises the results of those interviews. Responses fell into 51 categories with significant geographic variances. Top quartile data are the averages across the three cities. Of the 43 proposed reform options proffered, only one had significant support (50\%), being the imposition of inalienable fiduciary duty in the investment chain, support being greatest from Sydney respondents (70.59\%). This result is significant given Sydney's prominence in Australian funds management. Melbourne respondents $(n=5)$ had unanimous criticism of the prevalence of related party transactions. Their responses appear to be influenced by their proximity to the industry superfund sector, of which there was excoriating criticism. However, it is small sample size, but supports analysis reported in Heydon. 


\section{TABLE 3.20 Qualitative Research Results from Sydney, Melbourne, and Brisbane}

\begin{tabular}{|l|l|}
\hline Top Quartile & $\%$ Sample \\
\hline Related party transactions & \\
\hline Financial regulation in isolation: accretive tinkering: need trust principles & $60.71 \%$ \\
\hline Intrusion of 'black' letter law & $57.14 \%$ \\
\hline Conflicts of interest - related trustees \& investment managers/promoters/advisers & $50.00 \%$ \\
\hline Box ticking regulation by ASIC & $50.00 \%$ \\
\hline Financial planning not a profession & $46.43 \%$ \\
\hline Appearances of probity only: self interest rules & $46.43 \%$ \\
\hline Australian financial sector not internationally competitive in structure or fees & $39.29 \%$ \\
\hline Ineffective leadership at ASIC/ wrong leadership motivations & $35.71 \%$ \\
\hline Smart lawyer manipulation of complex 'black letter' law & $35.71 \%$ \\
\hline Financial planners should have unqualified best interest duty to client & $32.14 \%$ \\
\hline Boards need more independent minds & $32.14 \%$ \\
\hline Adviser financial literacy often flawed & $32.14 \%$ \\
\hline & $32.14 \%$ \\
\hline & \\
\hline Most favoured reform options & \\
\hline All to be subject to fiduciary principles & \\
\hline
\end{tabular}

\subsection{Systemic Causes of Failure Identified in the Empirical Legal Analysis}

\subsubsection{Methodology}

The senior court judgments have been analysed using the terminology in the judgments. That terminology is not always consistent. This analysis is summarised in Table 3.22 'Issues of Law', ranked by absolute incidence of the issue and expressed as a percentage of the total incidences in the sample (917 incidences) from 320 cases. Many cases involve multiple breaches of multiple statutes. The primary Corporations Act provisions are cited indicatively to clarify the descriptors, but there are often multiple breaches of that statute. Other oft quoted statutes include the Australian Securities and Investments Commission Act, Superannuation Industry (Supervision) Act, Australian Competition and Consumer Act (formerly Trade Practices Act), and National Consumer Credit Protection Act. 


\section{TABLE 3.21 Summary by Category, Funds Lost/Impaired and Investors Impacted}

\begin{tabular}{|c|c|c|c|}
\hline NBFE category & \# NBFE's with & Funds lost/permanently impaired & \# beneficiaries/investors impacted \\
\hline & authoritative empirical data & AUD million & \\
\hline Financial conglomerates & 15 & 14,731 & 112,634 \\
\hline Government rescued entities & 5 & 6,502 & 7 \\
\hline Insurance entities & 6 & 957 & 69,292 \\
\hline Hedge funds & 3 & 738 & 1,745 \\
\hline MIS/debenture schemes real estate & 56 & 10,423 & 291,517 \\
\hline MIS forestry $\&$ agribusiness & 23 & 6,826 & 169,590 \\
\hline Companies similar business model & 6 & 178 & 2,324 \\
\hline MIS infrastructure & 2 & 2,924 & 850 \\
\hline Securities broking \& leveraged lending & 8 & 1,105 & 2,304 \\
\hline Securities trading platforms & 12 & 226 & 5,647 \\
\hline Wealth management/financial planning & 43 & 4,018 & 423,741 \\
\hline Retail superannuation & 3 & 372 & 31,076 \\
\hline Industry superannuation & 5 & 2,918 & 291,458 \\
\hline Workers entitlement funds & 2 & 146 & 24,730 \\
\hline Other superannuation entities & $3 \mid$ & 105 & 1,370 \\
\hline Finance companies & $7 \mid$ & 81 & 487,323 \\
\hline TOTAL SAMPLE & 199 & 52,251 & $1,915,608$ \\
\hline
\end{tabular}

Commercial issues including mismatch of assets and liabilities and leverage (common in MIS) are not included in the analysis but are additional non-legal causes of NBFE failure. In many cases, particularly in real estate MIS, financial planning, superannuation and finance companies, large numbers of investors are impacted as a result of one incidence. There are comparatively few discrete incidences in financial literacy. This does not mean an absence of systemic failure. On the contrary, Table 3.22 demonstrates otherwise: it is a function of the number of discrete incidences reported by typology in the judgment which determines their empirical impact. Financial literacy cases include those involving informed consent and contributory negligence. Arguably, the prevalence of lawlessness in unlawful unregistered MIS, egregious behaviour in registered MIS, and unlicensed financial services businesses is a financial literacy category since the investing community should be knowledgeable enough to identify and avoid such cases. That is not so and the data has not been treated so in this analysis.

Similarly, where one entity the subject of judicial review operates multiple investment schemes (often a large number of registered and unregistered schemes), this is reported as one incidence of the issues in that judgment. Cases involving the antecedents of the Corporations Act (Corporations Law, State Companies Codes), and ASIC (State Corporate Affairs Commissions and 
Australian Securities Commission) are included in the equivalent modern Corporations Act

provision. Incidence of breaches of fiduciary duty are likely to be understated because many of the entities are not regarded as fiduciaries in Australian law and, if they are, have the legal ability to contract out of that relationship. 


\section{TABLE 3.22 Legal Matters Raised in the Judgments}

Legal matters raised in the judgments

\# by incidence $\%$ cases

Related party transactions CA s 191

Misleading \& deceptive/unconscionable conduct CA s 1041H, AA s 12DA, ACCA s 52

Fraud

Breach of fiduciary duties (statute \& general law) CA s 601FD

Financial services business CA s 911A/ financial advice CA s 781/ dealing CA s 780 without AFSL

Breach of good faith, proper purpose, best interest duty CA ss 181-184, 961 (FoFA)

Conflicts of interest \& duty CA s 191

Unregistered unlawful MIS CA s 601ED

Insolvency of NBFE (Incl RE/trustee)

Judicial/Court directions

Failure to properly disclose material matters CA s 191

Untrue/defective/misleading prospectus/PDS disclosure CA s 728

Improper financial advice

Uncommercia//unconscionable transactions

Breach of trustee \&/or RE duties (uncategorised)

Corporate governance failures/director competence/fit \& proper

Dishonesty/lack of integrity CA s 601FC,FD

Knowing assistance, receipt, accessorial liability, Barnes $v$ Addy

Breach of care \& diligence duty CA s 180

Reckless conduct

No lawful offer document CA s 1012,1013

Improper/ misleading accounting treatments

Ponzi scheme CA s 461

Negligence

Failure to properly keep books and records

Breach of auditor duty

Falsification of documents

Inability to provide informed consent

Public interest

Spurious valuations/no valuations

Continuous disclosure obligations/ ASX listing rules

Trust Acts (NSW, Qld, WA) ss 22, 59-63, 96

Breach of sole purpose test (superannuation) SIS Act s 62

Jurisdiction

Restraint on travel/passport forfeiture CA s 1323

Rescission/ab initio

Lack of fully informed consent

Constructive trust

Insider trading, market rigging, CA s 1043A

Privilege

Tortious liability

Briginshaw standard

No replacement RE/trustee

Court appointed investment manager

Calderbank offers

Improper custody of assets

Costs reasonable

Dividends out of capital

CA ss $601 \mathrm{NF}, 1325$,

Inaccurate forecasting disclosure

Breach of CA s 177

Breach of CA s 283DA

Breach of enforceable undertaking

Unauthorised reduction of capital

Chose in action

CA s 674

Inducement

CA ss 249D, 249N

Self dealing

Related party power of attorney

Total incidences in 320 cases

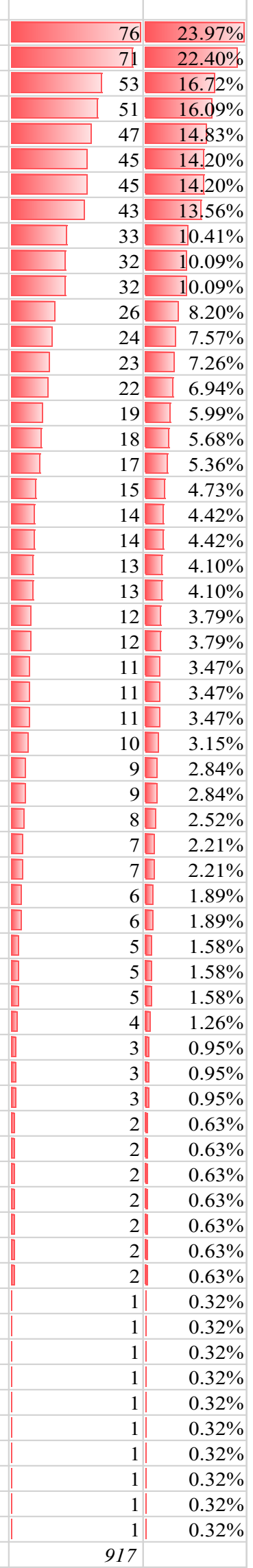




\subsubsection{Interpretation of Data}

This data has then been ranked as top decile and top quartile prevalence of the legal issues identified in the judgments. These are the top $10 \%$ and $25 \%$ issues of law identified in the judgments. For example, related party transactions recur in $22.16 \%$ of the top $10 \%$ of issues of law addressed in the judgments.

\section{TABLE 3.23 Prevalence of Issues of Law as Top Decile and Top Quartiles of Sample}

\begin{tabular}{|c|c|c|}
\hline Issues of law & Top decile prevalence & Top quartile prevalence \\
\hline & $\mathrm{n}=343$ incidences & $\mathrm{n}=623$ incidencies \\
\hline Related party transactions CA s 191 & $22.16 \%$ & $12.20 \%$ \\
\hline Misleading \& deceptive/unconscionable conduct CA s $1041 \mathrm{H}$, AA s 12DA, ACCA s 52 & $20.70 \%$ & $11.40 \%$ \\
\hline Fraud & $15.45 \%$ & $8.51 \%$ \\
\hline Breach of fiduciary duties (statute \& general law) CA s 601FD & $14.87 \%$ & $8.19 \%$ \\
\hline Financial services business CA s 911A/ financial advice CA s 781/ dealing CA s 780 without AFSL & $13.70 \%$ & $7.54 \%$ \\
\hline Breach of good faith, proper purpose, best interest duty CA ss 181-184, 961 (FoFA) & $13.12 \%$ & $7.22 \%$ \\
\hline Conflicts of interest \& duty CA s 191 & $13.12 \%$ & $7.22 \%$ \\
\hline Unregistered unlawful MIS CA s 601ED & & $6.90 \%$ \\
\hline Insolvency of NBFE (Incl RE/trustee) & & $5.30 \%$ \\
\hline Judicial/Court directions & & $5.14 \%$ \\
\hline Failure to properly disclose material matters CA s 191 & & $5.14 \%$ \\
\hline Untrue/defective/misleading prospectus/PDS disclosure CA s 728 & & $4.17 \%$ \\
\hline Improper financial advice & & $3.85 \%$ \\
\hline Uncommercial/unconscionable transactions & & $3.69 \%$ \\
\hline Breach of trustee \&/or RE duties (uncategorised) & & $3.53 \%$ \\
\hline
\end{tabular}

The primary issues of law have then been grouped into legal causes of systemic failure. Some of

these groupings include multiple issues of law, others which are discretely identified are reported as in Table 3.22. For example, dishonesty includes direct judicial references to dishonest conduct, but also includes judicial references to spurious valuations, lack of integrity, falsification of documents, fraud, self-dealing, Ponzi schemes, inducement, insider trading, and knowing assistance. Fiduciary duties includes instances of improper use of trust assets, breaches of State Trust Acts, auditor duty, and constructive trust. 
TABLE 3.24 Incidence of Systemic Failures in the Australian Regulatory System

\begin{tabular}{|l|r|r|}
\hline $\begin{array}{l}\text { Systemic failures } \\
\text { (by category) }\end{array}$ & \# by incidence \% incide nce \\
\hline Dishonesty & 128 & $15.98 \%$ \\
\hline Related parties/conflicts of interest CA s 191 & 122 & $15.23 \%$ \\
\hline Directors/trustee duties CA ss180-184, SISA s 62 & 119 & $15.23 \%$ \\
\hline Disclosure & 108 & $14.86 \%$ \\
\hline Misleading/deceptive/unconscionable conduct CA s 1041H, AA s 12Da, ACCA s 52 & 94 & $11.74 \%$ \\
\hline Fiduciary duty (statute \& general law) & 77 & $9.61 \%$ \\
\hline Financial advice CA ss 780,781,911; Unlicensed/breaches of AFSL & 71 & $8.86 \%$ \\
\hline Unlawful unregistered MIS CA 601ED & 43 & $5.37 \%$ \\
\hline Governance & 22 & $2.75 \%$ \\
\hline Financial literacy & 17 & $2.12 \%$ \\
\hline Total incidences & 801 & \\
\hline
\end{tabular}

\subsection{Predictive Veracity of the Empirical Data}

There are predictive insights to be derived from the top decile, top quartile, and systemic failures tables. Table 3.25 is a correlation analysis where the correlated incidence is greater or equal to $90 \%$ of the principal variable identified in top decile, top quartile and systemic failure tables. ${ }^{201}$ These are not regression analyses with dependent variables. It reports incidences derived from the judgments and correlates those incidences against each of the other variables listed. 199 case analyses is a statistically substantial sample. Therefore, it a reasonable hypothesis that this empirical analysis has predictive veracity, and by inference, to non-curial cases.

${ }^{201}$ For full correlation matrices, see Millhouse (n 1) app 2. 


\section{TABLE 3.25 Correlation Analysis of Principal Variables}

\begin{tabular}{|c|c|c|c|}
\hline Legal matters raised in the judgments & Variable & Recurrence \% of s ample & Correlation \\
\hline \multicolumn{4}{|l|}{ Top decile } \\
\hline Related party transactions CA s 191 & 1 & $22.16 \%$ & \\
\hline Misleading \& deceptive/unconscionable conduct CA s 1041H, AA s 12DA, ACCA s 52 & 2 & $20.70 \%$ & $93.42 \%$ \\
\hline \multicolumn{4}{|l|}{ Top quartile } \\
\hline Dishonesty & 1 & $15.98 \%$ & \\
\hline Related parties/conflicts of interest CA s 191 & 2 & $15.23 \%$ & $95.31 \%$ \\
\hline \multicolumn{4}{|l|}{ Systemic causes - first variable correlation } \\
\hline Dishonesty & 1 & $15.98 \%$ & \\
\hline Related parties/conflicts of interest CA s 191 & 2 & $15.23 \%$ & $95.31 \%$ \\
\hline Directors/trustee duties CA ss180-184, SISA s 62 & 3 & $15.23 \%$ & $95.31 \%$ \\
\hline Disclosure & 4 & $14.86 \%$ & $92.97 \%$ \\
\hline \multicolumn{4}{|l|}{ Systemic causes - second variable correlation } \\
\hline Related parties/conflicts of interest CA s 191 & 2 & $15.23 \%$ & \\
\hline Directors/trustee duties CA ss180-184, SISA s 62 & 3 & $15.23 \%$ & $100.00 \%$ \\
\hline
\end{tabular}

The correlation matrices point to substantial systemic risk buried deeply in the governance of entities in the financial system. Remedying this risk will require substantive law reform to eliminate or ameliorate its causes. A starting point is where matrices identify a $90 \%$ greater or equal correlation between the selected variables.

Related party transactions and misleading and deceptive conduct are closely correlated $(93.42 \%)$ - statistical siblings. There are high correlations between incidences of dishonesty, related parties/conflicts of interest (95.31\%), breaches of directors' fiduciary and best interest duties (95.31\%), and failures in disclosure (92.97\%). Where there are related parties, there will be conflicts of interest with an absolute correlation with breaches of directors' duties.

Directors, regulators and investors should focus their attention on any transaction where there are related parties. A review of the complete correlation tables identifies other areas of the law requiring reform and its enforcement. This data suggest that present law, or its enforcement, is not effective.

Incidences for which ASIC alone bears market conduct responsibility account for $81.23 \%$ of the sample. A minority of cases involve superannuation entities. There are relatively few judgments in the superannuation sector. Those cited, Commercial Nominees, Trio, Oasis, and some workers 
compensation MIS all involve related party transactions and resulted inter alia in fraud, misleading and deceptive conduct, asset impairment and direct consequential losses to superannuation and MIS beneficiaries.

If the predictive qualities of this empirical data are correct, then the publicly reported cases of related party transactions in industry superannuation entities need to be thoroughly investigated by APRA, in Workers Entitlement Funds by ASIC and the ROC. There are many instances of related party transactions, conflicts of interest, questionable adherence to the sole purpose test, and payments made of questionable veracity. Such egregious behaviour blights the history of Australian MIS, as Heydon and Hayne identified, and have recurred in financial conglomerates, whether NBFEs or otherwise.

\subsection{Cyclical Patterns of Behaviour 1981-2018}

The evidence suggests that evolution of the regulation and supervision of NBFEs falls into the four distinct periods identified in Chapter 2. Many cases have resulted in judicial intervention over many years. The dates attributed in Table 3.25 are the first date of intervention by administration or court referral, not the subsequent dates of the cases as reported. Table 3.26 illustrates its cyclical nature and pinpoints the commencement of each period. New cases also recur within these cycles. The peak in 1990 is a direct result of the regulatory environment through the 1980s (Deregulation and Entrepreneurship), its weaknesses exposed by the ASX correction of 1987 and the subsequent recession in Australia. From 2001 onwards, incidents of litigation increase as a result of a developing and more informed investment community and the advent of class actions (Disquiet). Some of these are attributable to the introduction of the Managed Investments Act in 1998. It significantly changed the nature of Australian collective investment scheme regulation. It facilitated the growth of the NBFE sector without providing for proper policy implementation. Regulatory and private litigation become prevalent from 2008 onwards as a direct (Reaction) to the manifest systemic failures in Australian regulation and supervision. As in 1990, the GFC in 2008/9 exposed 
those underlying failures, and provided cover to those seeking excuses. Subsequent years continue judicial intervention as cases are finalised, but do not of themselves provide more than tactical responses to specific legal and commercial issues through precedent and statutory accretion. Therefore, without substantive law reform, this historical analysis predicts that failures will continue to be exposed by a future macroeconomic event. 
TABLE 3.26 Cyclical Failure

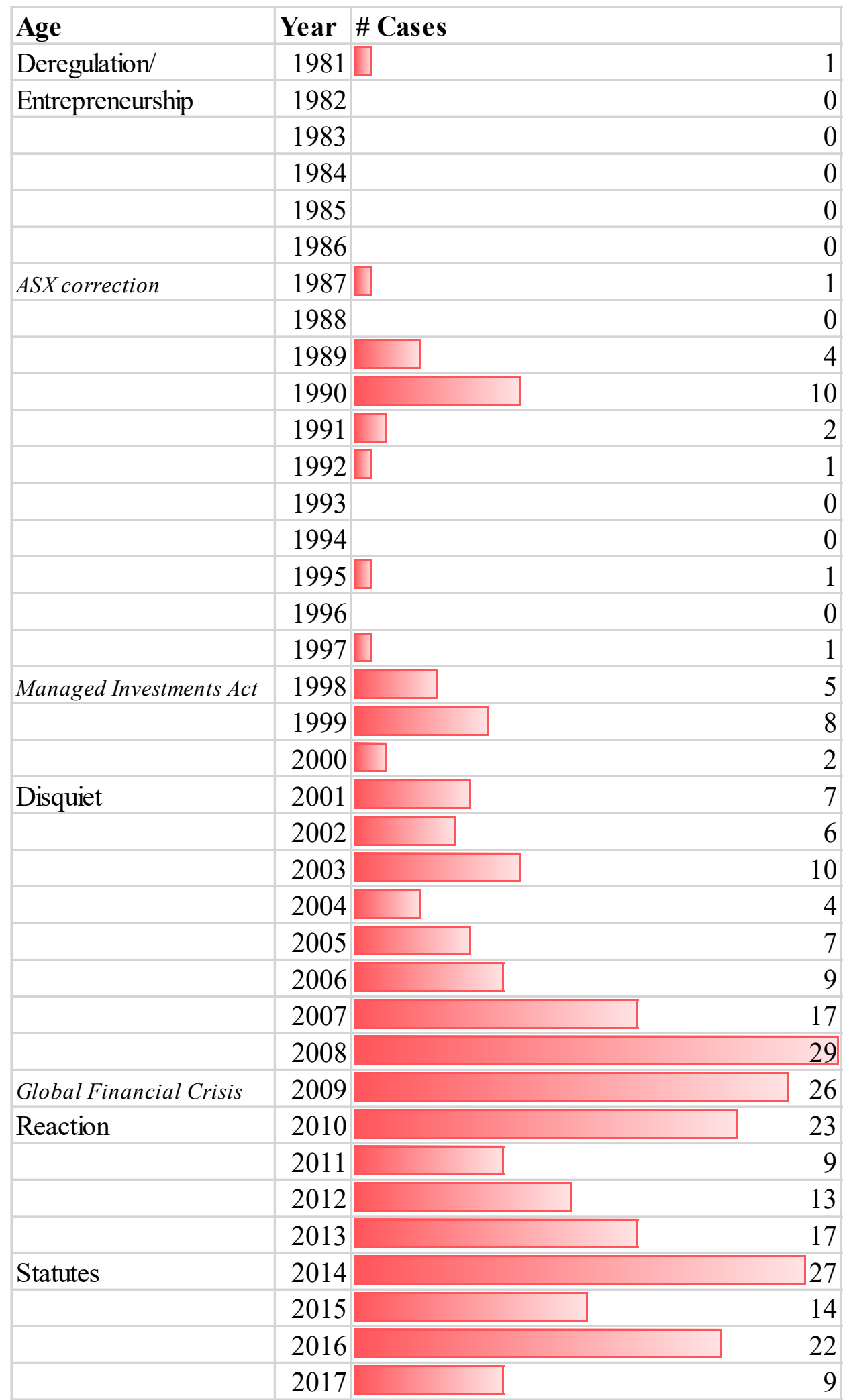




\subsection{Different Peaks: Different Outcomes}

The primary regulators are ASIC, APRA, and the ROC, previously the responsibility of the Fair Work Commission. Other regulators include the RBA, the ASX, the ACCC, State and NZ authorities. ASIC is involved with $100 \%$ of the sample, and of itself directly regulated $81.23 \%$ of them; ASIC and APRA together (Twin Peaks) regulated $11.08 \%$ of the sample. ASIC and the ROC regulated a further $2.15 \%$ of the sample (Triple Peaks). Despite the constant public criticism of ASIC, the data and the cases from which it is derived show ASIC to have been an active regulator. It was the plaintiff in $64.32 \%$ of the litigated cases. ${ }^{202}$ This implies that ASIC is not resource constrained. The deficiencies in desired outcomes therefore should be attributable to other causes.

These differences are explained by the different mandates and postures of each regulator. It is tempting, but erroneous to infer that ex ante supervision provides a better investor outcome than ex post market conduct regulation. ASIC's responsibility nationwide extends broadly to more than 2 million entities and much of their commercial activity. ASIC has the broadest mandate of any comparable regulator. APRA has a far fewer number of entities to supervise. Nonetheless, egregious behaviour has occurred in its supervised entities and within its different statutory constructs.

${ }^{202}$ Millhouse (n 1) app 3. 


\section{TABLE 3.27 Scope of Regulator Activity in the NBFE Sector}

\begin{tabular}{|l|r|r|}
\hline REGULATOR & & \\
\hline ASIC/ASC/CAC & 264 & $81.23 \%$ \\
\hline ASIC/ QLD OFT & 5 & $1.54 \%$ \\
\hline NZFMA & 4 & $1.23 \%$ \\
\hline APRA/ISC/ASIC & 36 & $11.08 \%$ \\
\hline ASIC/ASX & 1 & $0.31 \%$ \\
\hline FWC/ASIC & 7 & $2.15 \%$ \\
\hline ASIC/ATO & 7 & $2.15 \%$ \\
\hline ACCC & 1 & $0.31 \%$ \\
\hline Total interventions & 325 & \\
\hline
\end{tabular}

\subsection{Is Lawlessness Endemic in Australian Financial Services and Financial Products Markets?}

Unlicensed unlawful provision of financial services, financial products, and financial advice and unlawful unregistered MIS account for $14.23 \%$ of the incidences of systemic failure (Table 3.24) and $35.96 \%$ of all incidences in the sample (Table 3.22). Some of these incidences relate to the same case. These are both top quartile prevalence behaviours over the period of the sample, unprevented either by law enforcement or disciplines imposed by the investing public based on sound, unconflicted financial advice. Caveat emptor trumps fiduciary principles and statute. To illustrate, '[t]he schemes are generally designed so that all the investors ever receive are the pieces of paper constituting the agreements ... promoters design increasingly more sophisticated schemes in attempts to circumvent the laws'. ${ }^{203}$

${ }^{203}$ Australian Softwood Forests Pty Ltd v A-G (NSW); Ex Rel Corporate Affairs Commission [1981] HCA 49 [37] (Murphy J). 
Recognising that:

It would have been folly on the part of the legislature to attempt to define or limit what interests should be protected or how: to do so would have been to ignore the sad reality that the ingenuity of fraudsters [is] inexhaustible, their snares for the gullible pitiless and of infinite variety $\ldots{ }^{204}$

Folly indeed. As is the poacher becoming gamekeeper in 1998 subsuming fiduciary law beneath well-intended but poorly implemented statute, as the judicial responses analysed in Chapter 4 illustrate. Warning bells were ignored.

Malfeasance and egregious behaviour is not restricted to MIS: it occurs in funds controlled by registered organisations. ASIC's good intentions have been subverted by those ignorant of fiduciary obligations. Workers Entitlement Funds are MIS, exempted on an annual basis from Part 5C of the Corporations Act. ${ }^{205}$ These have been the subject of media disclosure and analysis by Heydon. There is a dearth of independent reliable empirical data which could be remedied by the Hayne Royal Commission with reform enforced by ASIC and the ROC.

\subsection{The Wallis Legacy: Disclosure, Financial Advice and Financial Literacy}

Implementation failures in these three Wallis principles are directly attributable for $25.84 \%$ of the incidences of systemic failure (Table 3.24). They are indirectly attributable to another $32.34 \%$, being a total of $58.18 \%$ of systemic incidences (Table 3.24 ). This is failure of law on a massive scale. This failure continues, with, on average, one new case per week attracting public attention

${ }^{204}$ Australian Securities and Investments Commission v Bridgecorp Finance Ltd [2006] NSWSC 836 [17] (Barrett J) citing Australian Securities and Investments Commission v Mauer-Swiss Securities Ltd [2002] NSWSC 684 (Palmer J).

${ }^{205}$ ASIC, ASIC Class Order: Employee Redundancy Funds: relief, CO 02/314 (2014); extended by ASIC Instrument: Corporations (Employee Relief) 2015/1150 (December 2015). ASIC has fashioned a new legislative instrument [CO 02/314] — ASIC Corporations (Employee Redundancy Funds Relief) Instrument 2015/1150 — to extend relief to 1 October 2018. 
from February 2018 to February 2019. It fails to recognise that investors are (forcibly) financial consumers, ${ }^{206}$ not suppliers of capital. 'Products [that] have been designed to be attractive to sell rather than meeting the needs of consumers'. 207

It explains community perceptions of ASIC and the frustrations with ASIC uncovered in the qualitative research but without their comprehension of ASIC being trapped in an ex post restrictive mandate. This empirical data cries out for reform of that mandate. The Managed Investments Act facilitated dramatic growth in the availability of collective investment opportunities but deficiencies in its implementation have contributed to large investor losses. Disclosure is not sufficient; financial advice has been conflicted and deficient, undisciplined by the necessary financial literacy of consumers unable to provide informed consent. Reliance on '[d]isclosure assumes that the capacities of financial consumers and retail investors are universal and rational, when research is showing that this is not the case'. ${ }^{208}$

\footnotetext{
${ }^{206}$ Kingsford Smith (n 28) 327-328.

${ }^{207}$ Ben Butler, 'Can a change of guard fix ASIC's image?', The Weekend Australian Business (Sydney), 2223 September 2018, 29 quoting Peter Kell, retiring ASIC Commissioner.

${ }^{208}$ Kingsford Smith (n 206) 330.
} 


\section{The Hayne Legacy of Law and Morality - A Regulatory Architecture for $21^{\text {st }}$ Century Australia}

\section{Empowering the Financial Consumer}

\subsection{Themes in Law Reform}

Hayne's 76 Recommendations of themselves are not enough. Mostly tactical and piecemeal, they have attracted criticism and disappointment. To some extent, he was constrained by the Letters Patent and time. Critics have largely missed that he also recommends system-wide long term reform. It is doctrinal, requiring absolute obedience to the spirit of the law to reflect community expectation of fiduciary trust and loyalty. It seeks to remove incentives for malfeasance and improve incentives for lifting standards rather than reliance on proscriptive and prescriptive boxticking compliance alone. His reform objectives require a framework — these proposals provide that framework. ${ }^{209}$

\subsection{Investors and Beneficiaries as Financial Consumers}

Future reform strategy should be financial consumer-centric, not supplier or regulator centric. Financially independent retirement for Australians is a pipe-dream if that focus is compromised. Consumer empowerment through improved financial literacy and destruction of power imbalances in the investment chain requires oversight outside of existing regulatory structures. 'An informed, expertly staffed and independent institution evaluating financial regulations and regulatory actions from the public's point of view'. ${ }^{210}$ This will allow different views to be heard, not subsumed by existing vested and politicised interests who will regroup and dilute proposed reforms that affect

\footnotetext{
${ }^{209}$ Millhouse (n 1) ch 6.

${ }^{210}$ Claessens and Kodres (n 191) 26 citing James Barth, Gerard Caprio and Ross Levine, Guardians of Finance (MIT Press, 2012).
} 
those interests. ${ }^{211}$ A specific purpose Reference Group with direct senior ministerial access is required.

Implementation will take 'significant time for construction, debate, refinement and implementation'. ${ }^{212}$ The qualitative research ${ }^{213}$ conducted in Melbourne, Sydney and Brisbane is insightful and proposes strategies consistent with jurisdictions that have better dealt with their own systemic failures. The top decile sources of failure identified by interviewees are: related party transactions, conflicts of interest, accretive statutory tinkering, intrusion of black letter law on trust principles, and box-ticking regulation by ASIC. Extended to the top quartile, this list adds: financial planning not being a profession, self-interest and lack of probity, ineffective leadership at ASIC, Australia's uncompetitive financial landscape, smart lawyer manipulation of complex black letter law, lack of unqualified best interest duty of financial planners, boards needing more independent minds, and flawed financial literacy of advisers.

\subsection{Itinera Fiduciae - Re-Establishment of Trust in the Investment Chain}

'We are never so vulnerable than when we trust someone'. ${ }^{214}$ Investment requires trust. Fiduciary obligation is the mirror of community expectation of trust in those that advise them or manage their funds. 'Fiduciary law cannot be subsumed under contract ... a violation of fiduciary duties carries a “moral taint". ... Unlike contract, trust is a moral relationship; its unwarranted violation is a moral principle'. ${ }^{215}$

${ }^{211}$ See, eg, M Scott Donald, 'Super needs a better regulator, not more rules' 6 November 2014 Australian Financial Review (Sydney) Editorial \& Opinion, 55.

${ }^{212}$ Ibid 30.

${ }^{213}$ Millhouse (n 1) ch 3 tab 3.20; app 1.

${ }^{214}$ Chan Sek Keong, 'Trusts and the rule of law in Singapore' (2013) 25 Singapore Academy of Law Journal 365.

${ }^{215}$ Richard Holton, 'Fiduciary Relations and the Nature of Trust' (2011) 91 Boston University Law Review 991, 994 quoting Tamar T Frankel, Fiduciary Law (Oxford University Press, 2011) 238. 
In Australia, there is a trust deficit. 'Since an underlying motivation of the imposition of fiduciary obligations is to maintain public confidence in socially important relationships like that of investment, the routine circumvention of such obligations raises public policy concerns' ${ }^{216}$

Fiduciary relationships can and should be found at every point in the investment chain where there is discretion, information, reliance or advice. The need is to re-establish foregone trust, confidence and respect in fiduciaries required to act as if they should be trusted. This outcome is unlikely to be achieved with prescriptive administrative regulation. It is 'not just a policy choice, but an architectural choice about how our law fits together' ${ }^{217}$ acknowledged by Hayne. The economic interests of investors and beneficiaries supported by holistic fiduciary standards in the investment chain is a different proposition from compliance with regulation. In the UK, as in Australia, it has led to a different result: creative compliance and creeping corruption. It also leads to different approaches to conflicts of interest. Identifying, disclosing and managing conflicts of interest in a complex investment chain controlled by multiple intermediaries is incompatible with the concept of a fiduciary having stewardship of client property if that fiduciary may have a conflict of interest.

Investor and beneficiary expectations (with statutory support in superannuation best interest law) include the optimisation of their value outcomes. What they typically attain, especially in Managed Investment Schemes (MIS) are contractual rights or legal interests. The economic consequences to the Australian economy are significant. Australia is not unique, but of the comparative jurisdictions studied, it has made the least progress addressing systemic problems in financial services and financial products regulation. When considering the re-establishment of trust, other jurisdictions follow one of two paths: (a) accretive statutory reform, or (b) the application of

\footnotetext{
${ }^{216}$ Tuch (n 13) 478, 516.

${ }^{217}$ Joshua Getzler, “'As If” - Accountability and Counterfactual Trust' (2011) 91 Boston University Law Review 973, 988.
} 
behavioural economics theory to regulation, leading to ex ante industry based regulation underpinned by universal fiduciary obligations.

Presently, Australia, the UK, and the US pursue accretive statutory reform, whilst Canada, Germany (with EU overlay), apply different legal mechanisms based on their fiduciary and duty of care traditions. These are not without criticism. ${ }^{218}$ Singapore pursues a culturally nuanced approach drawing upon legal tradition but implements German fiduciary-like standards of responsibility.

The application of behavioural economics research to financial regulation provides the theoretical basis for the imposition and extension of fiduciary principles to financial products and services. Each country has produced different but insightful results. There is recognition of the difference between compliance and values in Australian cases. ${ }^{219}$

\subsection{The Australian Enigma}

Australian law has uncertain interpretation of the fiduciary status of best interest duties. ${ }^{220}$ If Australian NBFE directors were themselves subject to Untreue ${ }^{221}$ doctrine (in its proscriptive and prescriptive formulations), supreme rather than subordinate, they would be less likely to hide

${ }^{218}$ Lisa Zhou, 'Fiduciary Law, Non-Economic Interests and Amici Curiae' (2008) 32(3) Melbourne University Law Review 1158.

${ }^{219}$ See, eg, Australian Securities and Investments Commission v Bridgecorp Finance Ltd [2006] NSWSC 836 [17] Barrett J citing Australian Securities and Investments Commission v Mauer-Swiss Securities Ltd [2002] NSWSC 684 Palmer J: '[I]t would have been folly on the part of the legislature to attempt to define or limit what interests should be protected or how: to do so would have been to ignore the sad reality that the ingenuity of fraudsters inexhaustible, their snares for the gullible pitiless and of infinite variety...'

${ }^{220}$ See Millhouse (n 1) ch 4 s 2.5 .

${ }^{221}$ A civil law duty of care doctrine, proscriptive, prescriptive, objective and subjective elements, a fiduciary like duty extending to the protection of third parties. Together with contractual culpa in contrahendo standards, results in Germany being closest to a pure liability model in financial advice with potential criminal consequences. These standards are now codified in EU law. 
behind transactional based disclosure requirements governed by statute and contract. The need to apply fiduciary law to investment banks (in their various formulations as financial conglomerates) has long been recognised in Australia. ${ }^{222}$

The future of trust rests upon fiduciary principles: these need the legal support of contractual culpa in contrahendo and Untreue standards. As judicially recently interpreted in Australia, fiduciary principles, compromised as they are by statute and contract, have not been sufficient to deter malfeasance. Where there have been green shoots of more enlightened interpretation, ${ }^{223}$ judicial reticence seeks to limit their broader application. '[I]t is important [to] preserve fiduciary law ... at least until a basis for expanding fiduciary law so that it incorporates prescriptive obligations is articulated rationally and accepted'. ${ }^{224}$

The deterrent effect of fiduciary law will require two components: these are (a) prohibition not prioritisation; and (b) prescriptive and positive duties to include financial best interest, meaning outcome, improved disclosure and education of the client to at least culpa in contrahendo standard. Informed consent should not be 'a merely formal process' ${ }^{225}$ That is to say, the implementation of the SRO model requires financial advisers to tutor their clients as they advise them in 'teachable moments'. It also means transferring financial literacy statutory responsibility from ASIC to the SROs through reform of the ASIC Act. This evolution is theoretically, culturally and organisationally sound, having a scholarly basis in behavioural economics research. It increases the financial literacy of the community, and provides the human resources ex ante at the interface when and where they are needed.

\footnotetext{
${ }^{222}$ See, eg, Tuch (n 13).

${ }^{223}$ Hospital Products Ltd v United States Surgical Corporation [1984] HCA 64 [100] (Gibbs CJ, Mason J).

${ }^{224}$ Matthew Harding, 'Two fiduciary fallacies' (2007) 2 Journal of Equity 1, 25.

${ }^{225}$ Getzler (n 217) 989.
} 
The imposition of statutory fiduciary duty directly in the investment chain has not been previously viewed with undiluted pleasure:

the controversial suggestion ... that the duty of directors to their 'company' can itself embrace some level of fiduciary responsibility to the beneficiaries of a trust of which their company is a trustee ... is questionable ... whether this heralded development in our law is as desirable or necessary one in the trust company context. ${ }^{226}$

However, 'superannuation entity director' is now enshrined in the SIS Act with direct fiduciary obligations to the beneficiary, ${ }^{227}$ and in the Corporations $A c t^{228}$ a best interest duty to MIS securities holders.

As Heydon ${ }^{229}$ also notes, cultural change to ensure 'reasonable expectations' ${ }^{230}$ of fiduciary obligations and principles is a generational task. That loyalty to others, enshrined in the general law but subsumed by statute and contract, should require reinforcement is a sad reflection on Parliament. It is a public policy issue to enforce effective disclosure, require effective conflicts avoidance and balance information and vulnerability asymmetries between provider and client. ${ }^{231}$

Law reform requires: (a) simplification and harmonisation of the various statutes; and, (b) renewed focus on fiduciary principles of propriety, honesty, and uncompromised loyalty. 'The fiduciary obligation is a demanding standard of propriety in conduct that is unequalled elsewhere in

\footnotetext{
${ }^{226}$ Australian Securities and Investments Commission v AS Nominees Limited, Ample Funds Limited, AS Securities Pty Ltd and Peter Grenfell Windsor [1995] FCA 1663 [77]-[78] (Finn J).

${ }^{227}$ Superannuation Legislation Amendment (Trustee Obligations and Prudential Standards) Act 2012 (Cth)

Explanatory Memorandum [1.33].

${ }^{228}$ Corporations Act 2001 (Cth) ss 601FD, 601FC.

${ }^{229}$ Heydon (n 3).

${ }^{230}$ Tuch (n 13) 483.

${ }^{231}$ Ibid 505.
} 
the law', ${ }^{232}$ requiring 'complete loyalty to the service of another's interests'. ${ }^{233}$ Any discussion of law reform needs to comprehend these two themes. The first imperative is better understood by reflecting on analysis of international practice in comparable jurisdictions. The second imperative will require a national sustained education campaign over a sustained period to inculcate industry participants in director, trustee, and officer roles with these fiduciary concepts. Training at university level is essential.

Presently in Australia, comprehension and application of fiduciary principles is not widespread, given lip-service, often ignored, eliminated in contract, and subservient to adherence to specific statutory provisions. Compliance with the letter of the law but not adherence to its spirit or community expectation. Canada and Germany have dealt with this problem applying their respective fiduciary and civil law duty of care standards. There is a public policy question as to whether Australian statutes 'adequately protects those to whom the general law would grant protection, if enforced, afforded by the fiduciary relationship'. ${ }^{234}$

\subsection{How Statutes Reduce Regulatory Efficacy: Subsuming of Fiduciary Principles by Statutory Accretion}

Empirical analysis demonstrates that the 'Age of Statutes' ${ }^{235}$ has not prevented, in any meaningful sense, an elimination of systemic problems nor of their cyclical recurrence: they may have added to the problem, ${ }^{236}$ and to judicial frustration. ${ }^{237}$ Misuse of 'fiduciary' the adjective by politicians and

\footnotetext{
${ }^{232}$ Ibid 479 citing Bristol \& West Building Society v Mothew [1998] Ch 1 [16] (Millett LJ).

${ }^{233}$ Ibid 481 citing P D Finn, 'The Fiduciary Principle' in T G Youdan (ed), Equity, Fiduciaries and Trusts

(Carswell, 1989) 1, 27.

${ }^{234}$ Ibid 514.

${ }^{235}$ Leeming (n 8).

${ }^{236}$ Millhouse (n 1) ch 3 tab 3.25.

${ }^{237}$ See, eg, ASIC $v$ Vines [2006] NSWSC [14] (Austin J): 'The application of the statutory language is difficult, because of the very wide range of activities conducted in corporate form'. Rares J succinctly
} 
lobby groups has resulted in a mismatch of community expectations based on common usage and the legal reality of fiduciary law in Australia. ${ }^{238}$

\section{Systemic Failure in Australian Law}

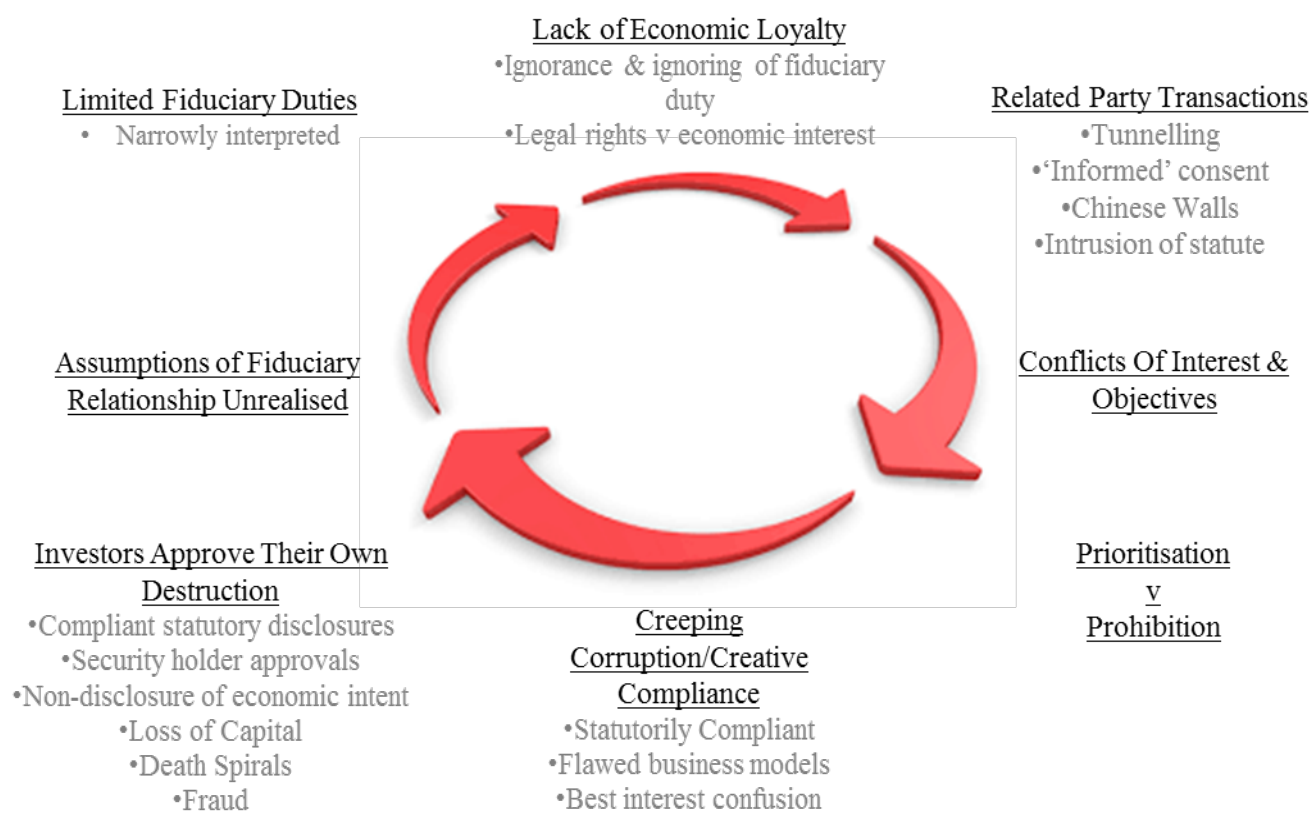

In many cases, contracts mean that fiduciary expectations are not legitimate... ${ }^{239}$ particularly in Australian NBFEs. Judicial reticence to interfere in arms-length contracting parties ${ }^{240}$ where best

expressed his frustrations with statutory accretion in Wingecarribee Shire Council v Lehman Brothers Australia Ltd (in Liq) [2012] FCA 1028 (Rares J) noting the Corporations Act and ASIC Act have lengthy and different definitions of financial services and financial products: he questions the costs of statutory complexity to the community, see Millhouse (n 1) ch 4 s 4.1.1. S 62 of the SIS Act is 'complex, clumsy and lacks clarity ... it takes over 900 words to say that a superannuation fund must be set up to provide benefits ...' quoted in Anthony Asher, Superannuation 'objective' likely to be captured by industry (The Conversation, April 2016), <https://the conversation.com>.

${ }^{238}$ Donald (n 9) [1].

${ }^{239}$ Fiduciary Duties of Investment Intermediaries (Paper No 350) (n 79) [8.48].

${ }^{240}$ Hospital Products Ltd v United States Surgical Corporation [1984] HCA 64 [100]-[102] 71 (Gibbs CJ, Mason, Wilson, Deane and Dawson JJ) citing Paul Dainty Pty Ltd v National Tennis Centre Trust (1990) 22 FCR 495, 515-516. 
interest of clients are contractually overridden does not assist the vulnerable to mount equitable challenges to malfeasance.

Even where the relationship is contractual (as it normally will be), the matter is too important to be left entirely to the agreement of the parties and the interpretation of that agreement ... A too casual failure to recognise the requirements of a fiduciary position, and sometimes a short sighted assumption that all relevant duties are prescribed in contract, can be and has been responsible for serious misbehaviour in the financial markets and elsewhere, as shown by many litigated cases in the last quarter-century. ${ }^{241}$

Assuming that statutory regulation alone can drive market behaviour is problematic. In practice, as in Canada and Germany, the intertwined European and national jurisdiction mix of misnamed soft law through self-regulation, co-regulation, and government regulation, disciplined by the primacy of fiduciary principles and the statutory powers of minority shareholders has resulted in 'Firms begin to avail themselves of corporate governance principles codes, guidelines and laws, thereby leaving the "box-ticking" phase behind'. ${ }^{242}$ This is a salutary lesson for present Australian practice, its Corporations Act facilitating creeping corruption in MIS and other NBFEs through box-ticking compliance.

The disconnection between community expectation and legal reality must be addressed. Community assumptions of fiduciary obligation of economic loyalty to investors by professional persons with whom they deal is not fact. The exposure of the legal reality will mean further community anger.

${ }^{241}$ Fiduciary Duties of Investment Advisers (Law Commission UK Consultation Paper No 215, 22 October 2013) 171 citing Peter Watt (ed), Bowstead \& Reynolds on Agency (Sweet \& Maxwell, 19 ${ }^{\text {th }}$ ed, 2010) [6-043].

${ }^{242}$ Joseph A McCahery and Erik P M Vermuelen, 'Private Equity and Hedge Fund Activism: Explaining the Differences in Regulatory Responses' (2008) 9 European Business Organization Law Review 535, 537. 


\subsection{Clarity in Law: Harmonisation of Best Interest Duty}

There are five interpretations of best interest in the Corporations $A c t^{243}$ (Hayne proposes a sixth), two in the SIS Act, ${ }^{244}$ a traditionally lesser duty in the Fair Work (Registered Organisations Act) (now amended) as well as general law interpretations, fiduciary or otherwise, which add to the confusion. ${ }^{245}$ Whilst these interpretations are contextual they are, with limited exceptions, statutorily undefined. The community, and directors responsible to it in the performance of their duties, should not be expected to comprehend these nuances, for the most part determined in the general law. ${ }^{246}$ Whether the superlative 'best' has legal meaning at all, ${ }^{247}$ or whether it raises community expectations which are different from their legal basis further confuses present Australian law.

\subsection{Hayne and Beyond}

The messages from Hayne, Heydon and the Productivity Commission are very clear. Government must act. It must do so strategically, without fear or favour. Only then will trust return, and capital flows to those enterprises that need it. Australia is at a cross-roads - 2019 must be the start of the Age of Trust.

${ }^{243}$ Corporations Act 2001 (Cth) ss 180-4, 601 FC (1), 601 FD (1)(b), 961B(1)(2).

${ }^{244}$ Superannuation Industry (Supervision) Act 1993 ss 52(2), 52(8), VN(a)-(b).

${ }^{245}$ See, eg, ASIC v Australian Property Custodian Holdings Limited (Receivers and Managers appointed) (in liquidation) (Controllers appointed) (No 3) [2013] FCA 1342 (12 December 2013) [463] (Murphy J), Lewski v ASIC [2016] FCAFC 96 [347] (Greenwood, Middleton, and Foster JJ); Lewski v ASIC (No 2) [2017] FCAFC 171 [190] (Greenwood, Middleton, and Foster JJ) ['Prime Trust'].

${ }^{246}$ See, eg, Millhouse (n 1) ch 1 s 11.

${ }^{247}$ David Pollard, 'The Short-form "Best Interests Duty" — Mad, Bad and Dangerous to Know: Part 1 Background, Cowan v Scargull and MNRPF' (2018) 32(2) Trust Law International 106 cited in M Scott Donald, Submission to Royal Commission into Misconduct in the Banking, Superannuation and Financial Services Industry (21 September 2018) [3]. 